\title{
Validating the Paradigm That Biomechanical Forces Regulate Embryonic Cardiovascular Morphogenesis and Are Fundamental in the Etiology of Congenital Heart Disease
}

\author{
Bradley B. Keller ${ }^{1, *}$, William J. Kowalski ${ }^{2}$, Joseph P. Tinney ${ }^{3}$, Kimimasa Tobita ${ }^{4} \mathbb{C}$ \\ and Norman $\mathrm{Hu}^{5}$ \\ 1 Cincinnati Children's Heart Institute, Greater Louisville and Western Kentucky Practice, \\ Louisville, KY 40202, USA \\ 2 Laboratory of Stem Cell and Neuro-Vascular Biology, Cell and Developmental Biology Center, National \\ Heart, Lung, and Blood Institute, NIH, Bethesda, MD 20892, USA; william.kowalski@nih.gov \\ 3 Kosair Charities Pediatric Heart Research Program, Cardiovascular Innovation Institute, University of \\ Louisville, Louisville, KY 40202, USA; joetnn1@gmail.com \\ 4 Department of Medical Affairs, Abiomed Japan K.K., Muromachi Higashi Mitsui Bldg, \\ Tokyo 103-0022, Japan; ktobita1103@gmail.com \\ 5 Department of Pediatrics, University of Utah, Salt Lake City, UT 84108, USA; Norm.Hu@hsc.utah.edu \\ * Correspondence: brad.keller@cchmc.org
}

Academic Editor: Andy Wessels

Received: 15 May 2020; Accepted: 10 June 2020; Published: 12 June 2020

\begin{abstract}
The goal of this review is to provide a broad overview of the biomechanical maturation and regulation of vertebrate cardiovascular $(\mathrm{CV})$ morphogenesis and the evidence for mechanistic relationships between function and form relevant to the origins of congenital heart disease (CHD). The embryonic heart has been investigated for over a century, initially focusing on the chick embryo due to the opportunity to isolate and investigate myocardial electromechanical maturation, the ability to directly instrument and measure normal cardiac function, intervene to alter ventricular loading conditions, and then investigate changes in functional and structural maturation to deduce mechanism. The paradigm of "Develop and validate quantitative techniques, describe normal, perturb the system, describe abnormal, then deduce mechanisms" was taught to many young investigators by Dr. Edward B. Clark and then validated by a rapidly expanding number of teams dedicated to investigate $\mathrm{CV}$ morphogenesis, structure-function relationships, and pathogenic mechanisms of CHD. Pioneering studies using the chick embryo model rapidly expanded into a broad range of model systems, particularly the mouse and zebrafish, to investigate the interdependent genetic and biomechanical regulation of $\mathrm{CV}$ morphogenesis. Several central morphogenic themes have emerged. First, CV morphogenesis is inherently dependent upon the biomechanical forces that influence cell and tissue growth and remodeling. Second, embryonic CV systems dynamically adapt to changes in biomechanical loading conditions similar to mature systems. Third, biomechanical loading conditions dynamically impact and are regulated by genetic morphogenic systems. Fourth, advanced imaging techniques coupled with computational modeling provide novel insights to validate regulatory mechanisms. Finally, insights regarding the genetic and biomechanical regulation of $\mathrm{CV}$ morphogenesis and adaptation are relevant to current regenerative strategies for patients with CHD.
\end{abstract}

Keywords: avian embryo; biomechanics; cardiovascular morphogenesis; computational modeling; congenital heart disease; hemodynamics; impedance; mouse embryo; pressure-volume relations; shear stress; ventricular function; ventricular-vascular coupling; zebrafish embryo 


\section{Introduction}

The embryonic heart has been the subject of intense investigation for over a century. Initially, the chick embryo was the focus for academic investigation due to the opportunity to characterize morphogenesis via careful serial sections and histology [1-8] the opportunity to isolate and investigate myocardial electromechanical maturation [9-11], the ability to directly observe via light microscopy [12-16], instrument [17-23] and measure normal cardiac function using fluid-filled pipettes [24-26], and the interest of investigators to explore the consequences of increased and decreased ventricular loading conditions on cardiovascular (CV) morphogenesis [27-29]. The key findings of these studies included the progressive electrophysiologic maturation of the developing myocardium, the ability of the heart to generate phasic pressure and pulsatile blood flow in the absence of mature cardiac valves, including the contribution of the contracting conotruncus (CT) in the early embryo [21] and the impact of altered intracardiac blood flow on ventricular and vascular morphogenesis. Approaches explored in avian embryos [30-34] have broadened to mammalian embryos with advances in murine genetic models [35-37] and Drosophila [38], Xenopus [39], and zebrafish embryos [40] due to the ease of fate mapping and genetic tools, and have been applied to understand the opportunities for intervention and prevention in the human embryo and fetus [41-43].

Due to both the high morbidity and mortality associated with congenital heart disease (CHD) [44], determining the origins of congenital CV malformations has been the fascinating pursuit of an extensive community of international investigators and institutions. Early descriptions of CHD focused on the structural defects, concurrent altered CV function, and subsequent morbidity and mortality [45]. Prior to 1985, CHD was calculated to occur in up to $1 \%$ of the population [46], living at sea level, as the result of teratogenic or random errors in morphogenesis, but with uncertain underlying genetic mechanisms [47]. Patterns of CHD lesions were logically segmented into a pathogenic classification schema that included abnormalities in (1) ectomesenchymal tissue migration; (2) intracardiac blood flow; (3) cell death; (4) the extracellular matrix; (5) targeted growth; and (6) situs and looping [48,49]. Careful population studies launched a new era of quantitative epidemiologic investigations on the prevalence and associations of CHD with maternal conditions [50] followed by the rapid expansion of experimental investigations on the mechanistic origins of CHD [51,52].

In the early 1980s, Dr. Edward Clark and Norman Hu launched a series of pioneering studies to quantify the normal functional maturation of the embryonic chick CV system using higher fidelity pressure-recording systems and the application of piezoelectric crystal recorded pulsed Doppler velocimetry followed by an expanded investigation of the consequences of altered metabolic and biochemical stressors as well as altered biomechanical loading on developing cardiac structure and function. These pioneering studies were then coupled to computational approaches to investigate cardiac biomechanics and the central paradigm that biomechanical forces regulate embryonic $\mathrm{CV}$ morphogenesis and are fundamental in the etiology of CHD has now been validated in multiple vertebrate species using the broadest range of investigative techniques.

\section{Quantifying Embryonic CV Structure-Function Relationships Using Servo-Null Pressure and Pulsed-Doppler Velocity Recordings}

The development and validation of reproducible, quantitative experimental techniques was fundamental to the Clark and $\mathrm{Hu}$ approach to exploring embryonic structure-function relationships in the chick embryo. Chick embryo stages based on external morphology [2], which represented sequential doublings of embryo mass, stages 18,21, 24, and 27, were chosen to reflect increased cardiac and metabolic demand. Phasic pressures were recorded using a salt-solution-filled capillary tube and a servo-null system, and blood velocity was recorded using a piezoelectric crystal pulsed Doppler system (Figure 1). This pivotal study confirms that stroke volume (SV) and embryonic systolic, diastolic, and mean blood pressures increase with development, cardiac output indexed to embryo weight remains constant over an 8-fold increase in embryo mass and vascular resistance decreased consistent with increased aortic diameter as well as expansion of distal vasculature beds [53]. 
Expanded investigations of the chick embryo hemodynamics, including the measurement of phasic atrioventricular, ventricular, dorsal aortic and vitelline arterial pressures and blood velocities (Figure 2), embryo and ventricular weights, and myocardial myocyte organelle composition confirmed a linear $\log -\log$ relationship between ventricular and embryo wet weight, increasing ventricular and dorsal aortic pressure during development, increasing myofibrillar content with constant mitochondrial content [54-58].

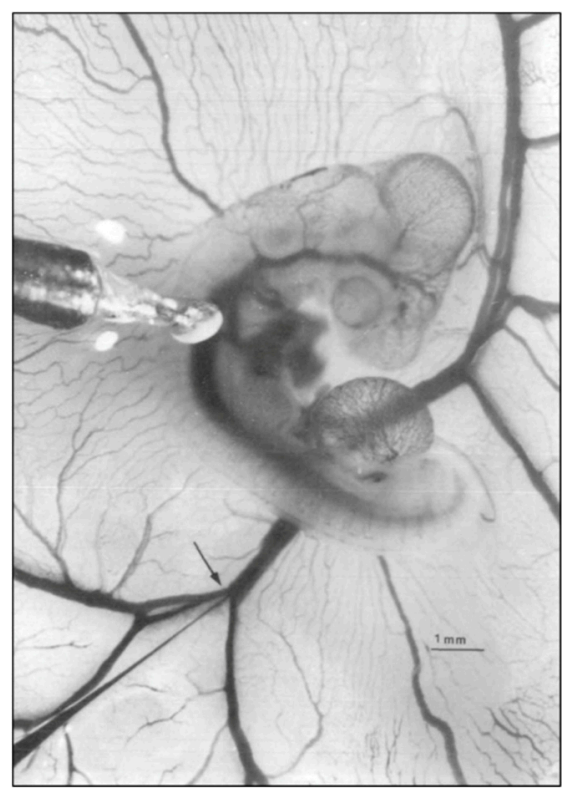

Figure 1. Representative photo of a stage 21 chick embryo for hemodynamic measurements. A 1-mm diameter piezoelectric crystal is positioned over the dorsal aorta at a $45^{\circ}$ angle and a $5 \mathrm{~mm}$ diameter tip glass micropipette is positioned in the left vitelline vein. Scale bar $=1 \mathrm{~mm}$. This image was reproduced with permission [53].

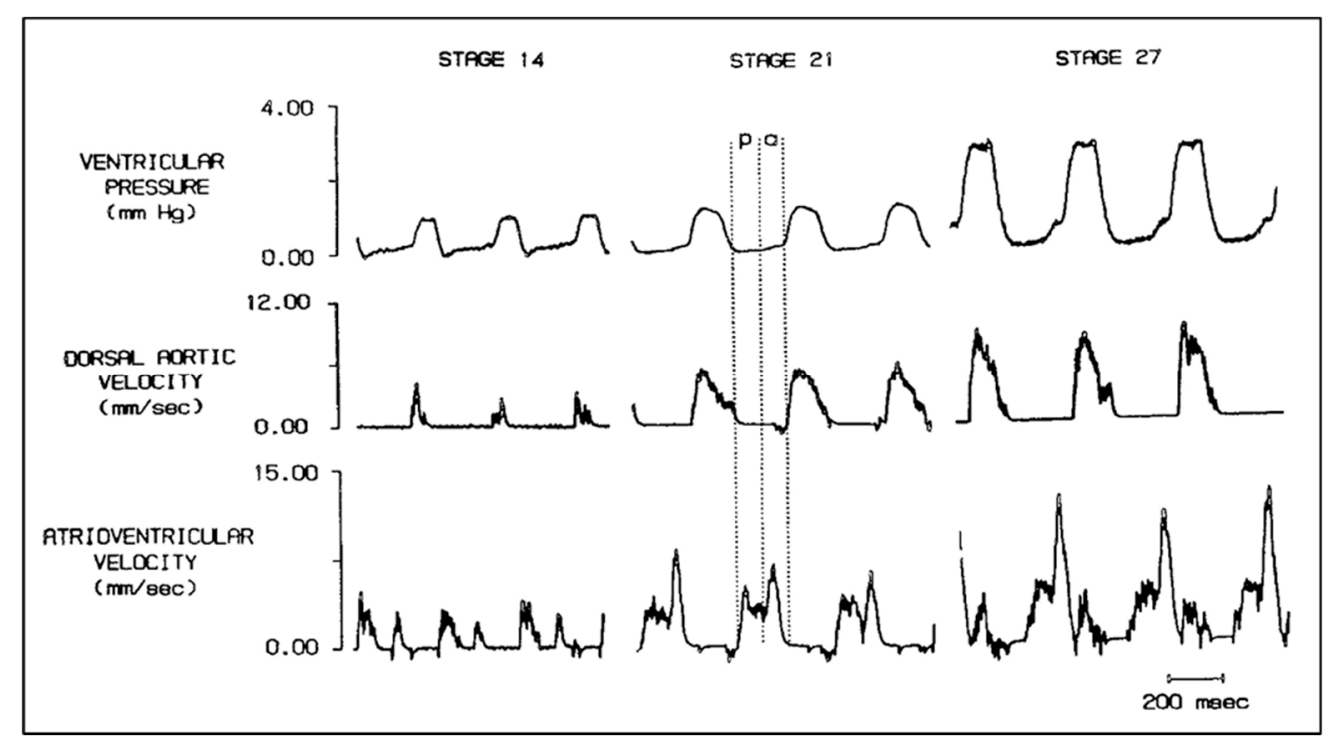

Figure 2. Simultaneous ventricular pressure, dorsal aortic velocity and atrioventricular velocity in stage 14, 21, and 27 chick embryos. Diastole is partitioned into the passive filling phase (p) followed by active ventricular filling due to atrial systole $(\mathbf{a})$. Scale bar $=200$ milliseconds $(\mathrm{msec})$. This was reproduced with permission [56]. 
These normative data set the stage for a rapid expansion of studies that investigated the ability of the developing embryonic CV system to adapt to acute and chronic challenges [52,59-64]. Changes in embryo temperature showed that heart rate and cardiac output are temperature dependent and that peripheral resistance changed inversely to cardiac output $[65,66]$. Normal heart rate and normal $\mathrm{AV}$ conduction are required for optimal cardiac output [67-69], and SV changes in response to altered circulating blood volume [70]. A range of pharmacologic and metabolic treatments confirmed the impact of acute changes in myocardial contractility on embryonic CV function [71-79] and that the embryonic myocardial response to beta-adrenergic receptor stimulation was due to changes in peripheral vascular resistance rather than to changes in heart rate or contractility [80] prior to functional innervation [81].

\section{Applying Adult Ventricular Biomechanics Paradigms to the Rapidly Developing Embryonic Chick CV System}

Quantifying adult myocardial performance using load-dependent and load independent paradigms was a central theme of the adult cardiology and CV bioengineering programs at the Johns Hopkins Hospital at the same time the Clark and $\mathrm{Hu}$ lab was exploring the regulation of embryonic CV structure-function relations. Pivotal papers defined CV function using pressure-volume (PV) relations [82-86] and the impact of ventricular-vascular coupling on myocardial performance [87-90]. Based on the evidence that embryonic CV performance was carefully regulated despite dramatic differences in scale and maturation, the investigation of a PV paradigm in the embryonic chick became a new focus of the Clark and $\mathrm{Hu}$ lab and facilitated the adaptation of biomechanical models of the mature circulation to embryonic CV morphogenesis and adaptation.

\section{Initial Observations on Embryonic Ventricular and Atrial Pressure-Area Relations}

Applying a PV paradigm to the embryonic chick heart required the adaptation of available methods to quantify dynamic changes in cardiac dimensions during the simultaneous recording of ventricular pressure. Video microscopy of the beating embryonic heart $[14,22,91]$ was adapted to correlate changes in ventricular dimensions (perimeter, cross-sectional area) with ventricular mass and function [92]. Using a brief direct voltage pulse to brighten a video field concurrent with placing a mark on paper chart, phasic ventricular tracing synchronized embryonic chick ventricular pressure and area data and confirmed that the embryonic heart had filling, isometric contraction, ejection, and isometric relaxation phases, similar to the much larger adult heart (Figure 3) [21,93].

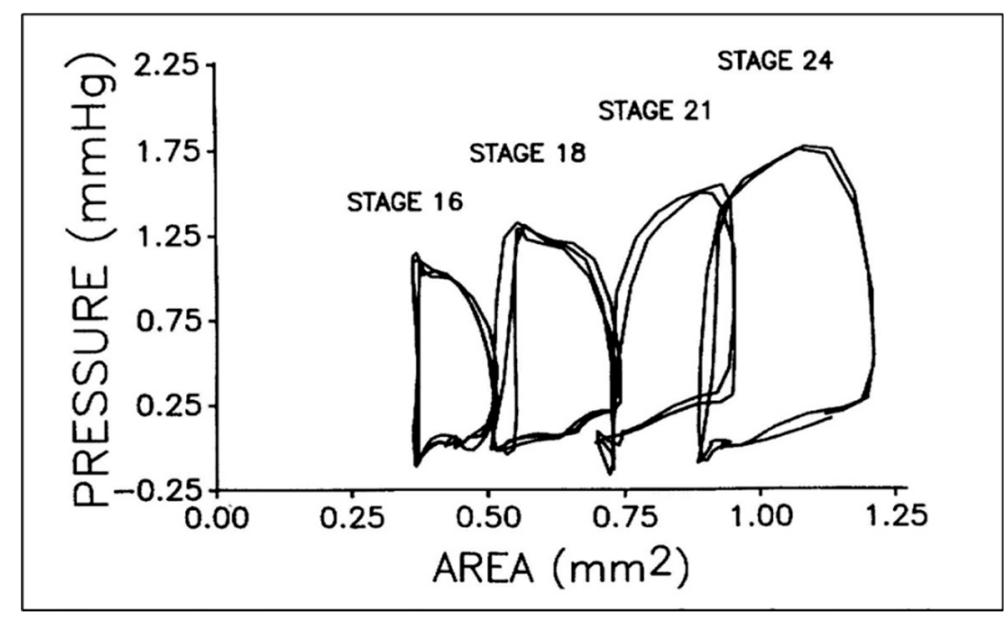

Figure 3. Representative pressure-area loops for stage 16 to 24 chick embryos. Two or three cardiac cycles are included for each stage as synchronized, raw data. This was reproduced with permission [93]. 
Using a simple ellipsoid equation to convert area to volume, embryonic PV loops displayed an end-systolic pressure volume relationship and ventricular-vascular coupling typical of the mature circulation (Figure 4) and also displayed maturation-dependent ejection characteristics consistent with decreasing vascular resistance during geometric vascular expansion [94-97]. The ability to increase embryonic ventricular systolic pressure in response to volume loading suggested that the presence of contractile reserve that was initially shown using ventricular pressure measurements during outflow tract occlusion to generate isovolumic beats [22] and then confirmed in PV loops during acute conotruncal clamp [98].

A.

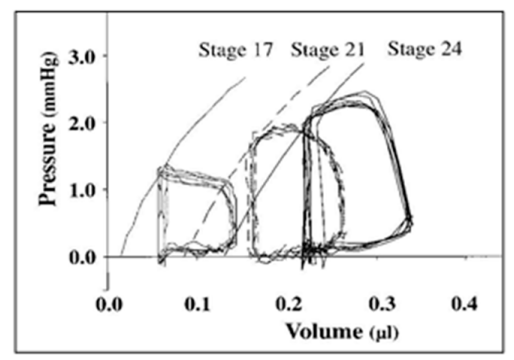

B.

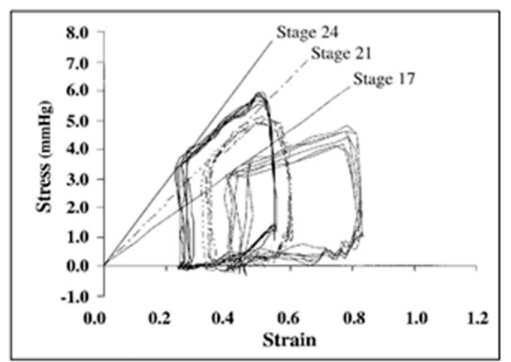

Figure 4. Representative pressure-volume (A) and stress-strain (B) loops for stage 17, 21, and 24 chick embryos. End-systolic pressure-volume relations were curvilinear, end-systolic stress-strain relations were linear, and end-systolic myocardial stiffness increased with development. This was reproduced with permission [97].

A similar approach allowed for the description of passive and active atrioventricular (AV) coupling using simultaneous recordings of atrial and ventricular pressure [99], atrial pressure-area loops, and simultaneous AV doppler velocity recordings [100]. Early stage embryos displayed ventricular filling velocities consistent with a relatively non-compliant chamber with increasing passive filling during ventricular expansion [56]. Acute changes in heart rate produce inverse changes in ventricular pressure and SV (Figure 5) [21,101], though dorsal aortic blood flow is maximal at intrinsic heart rates [102,103]. PV analysis showed that isovolumic contraction time remained independent of cycle length, while ventricular end-diastolic filling times, end diastolic volumes, and SV varied linearly with cycle length [104]. One surprising observation from this embryonic PV loop study was that, in contrast to the mature circulation, the relationship between SV and end-systolic pressure was inverse [104], suggesting the immature embryonic vasculature rapidly vasodilates in response to increased SV and constricts in response to reduced SV in the absence of muscularized vessels or a functioning autonomic system [81].

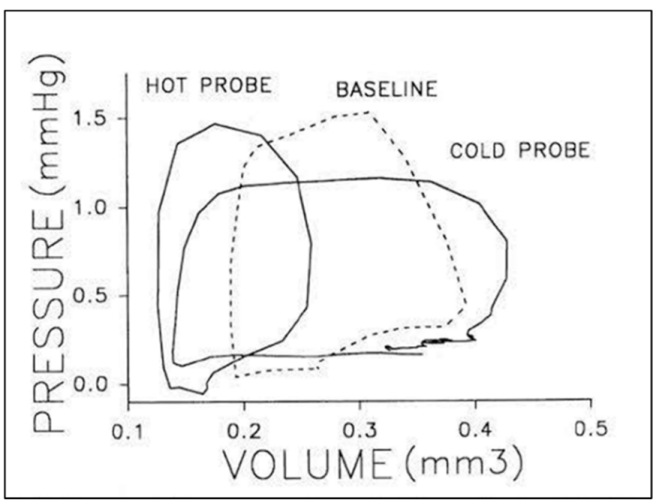

Figure 5. Representative pressure-volume loops for a stage 21 chick embryo at baseline (dashed line), intrinsic heart rate then in response thermal probe application to increased (hot) or decreased (cold) heart rate. Two or three cardiac cycles are included for each stage as synchronized, raw data. This was reproduced with permission [104]. 


\section{Embryonic Hemodynamic and Hydraulic Ventricular-Vascular Coupling}

Similar to the mature circulation, embryonic ventricular-vascular coupling is an essential attribute of developmental CV physiology and is evident from the onset of cardiac contraction in the chick embryo. Video microscopy of the embryonic conotruncal cushions during the cardiac cycle reveals that the cushions are separated at the end of ventricular ejection, yet there is no retrograde flow back into the ventricle during diastole at the intrinsic heart rate and blood volume [92]. Volume infusion and withdrawal and acute changes in heart rate confirmed the ability of the embryonic circulation to rapidly accommodate changes in cardiac output despite the structural simplicity of the developing vasculature $[22,70,94,104]$. Curvilinearity in the adult end-systolic PV relationship [89] is more prominent in the embryonic circulation due to reduced arterial impedance in response to increased stoke volume [94]. Aortic impedance, calculated from simultaneous measurement aortic pressure and blood velocity provide a robust description of hydraulic load on the ventricle and can impact ventricular ejection characteristics, including the contour of the arterial pressure waveform and SV $[87,105,106]$.

The simultaneous measurement of servo-null dorsal aortic pressure and pulsed-doppler velocity reveals that embryonic chick arterial impedance displays maturational features consistent with decreasing afterload and increasing hydraulic power [107]. In contrast to the mature circulation where approximately $10 \%$ of hydraulic power is expended in pulsatility, the embryonic circulation shows a steep increase in oscillatory power, up to $65 \%$ by stage 29 , which may be important in driving vascular morphogenesis [107]. Aortic impedance analysis in the stage 24 chick embryo using a 3-element windkessel model (Figure 6A) displayed features similar to the mature arterial tree despite an embryonic aortic diameter of less than $1 \mathrm{~mm}$ and an arterial pressure of $1 / 70^{\text {th }}$ of the mature circulation [108]. Furthermore, compensatory changes in arterial compliance, hydraulic power, and peripheral resistance occurred in response to volume withdrawal and reinfusion and a hysteresis "lag" suggested that circulating vasoactive substances or mechanical properties of the peripheral vasculature may be an important determinant in the dynamic response to changes in cardiac output $[108,109]$. The refinement of the embryonic arterial impedance representation using analog windkessel models showed that 3- and 4- element windkessel models confirmed the similarity between embryonic and mature vascular systems, including flow-wave propagation, despise dramatic differences in scale and geometry (Figure 6B,C) [110-112]. Dual instrumentation by positioning piezo-electric crystals to simultaneously measure proximal and distal dorsal aorta blood velocity waveforms allows for the quantification of pulse-wave velocities [111,113], providing additional insights into the maturation of embryonic arterial properties.

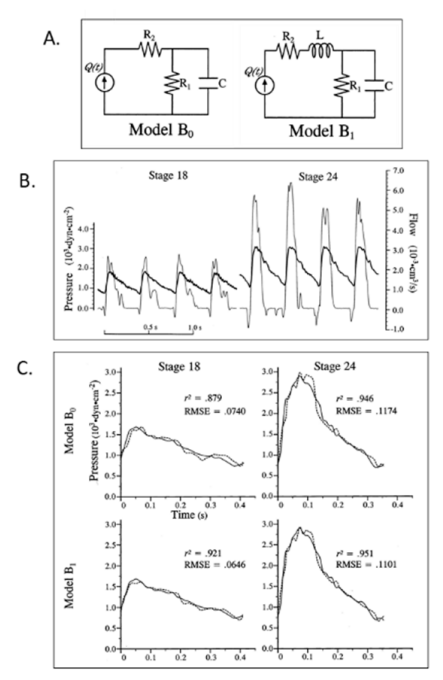

Figure 6. Lumped parameter Windkessel estimation of embryonic chick arterial impedance. (A) 3-element $\left(\mathrm{B}_{0}\right)$ and 4-element $\left(\mathrm{B}_{1}\right)$ lumped parameter models of the embryonic circulation as 
electrical circuit analogs; (B) representative time domain pressure and flow waveforms for stage 18 and 24 chick embryos. Bold lines represent pressure and thin lines represent blood flow data; $(\mathbf{C})$ representative fit results based on models $B_{0}$ and $B_{1}$ for stage 18 and 24 data. Solid lines represent experimental pressure data and dashed lines represent model-predicted pressure waveforms. $r^{2}$, the coefficient of determination; RMSE, root mean square error. This was reproduced with permission [102].

In addition to the regulation of embryonic ventricular afterload, pharmacologic studies confirmed that the embryonic circulation dynamically adapts venous return and ventricular preload in response to vasoactive substances. Nitroprusside [114] and atrial natriuretic peptide acts as a venodilator to reduce ventricular preload in the embryonic circulation prior to maturation of the brain or kidney [75]. Venous preload is particularly important in the embryonic heart due to the dependence on passive filling of the early heart tube [56,104].

\section{Embryonic Ventricular and Vascular Biomechanics}

Isolated strips of embryonic chick myocardium have been a classic experimental model to investigate the maturation of myocardial contractility [9-11]. Isolated embryonic chick ventricular strips display significant hysteresis [115], consistent with the viscoelastic behavior of adult tissues [116] and with the hysteresis noted during cyclic inflations of the isolated passive heart [117]. Isolated embryonic chick myocardium displays force-frequency relationships consistent with immature calcium cycling (Figure 7) [77,118-123]. Passive stiffness in isolated left ventricular (LV) strips correlates with microtubule content and polymerization [124].

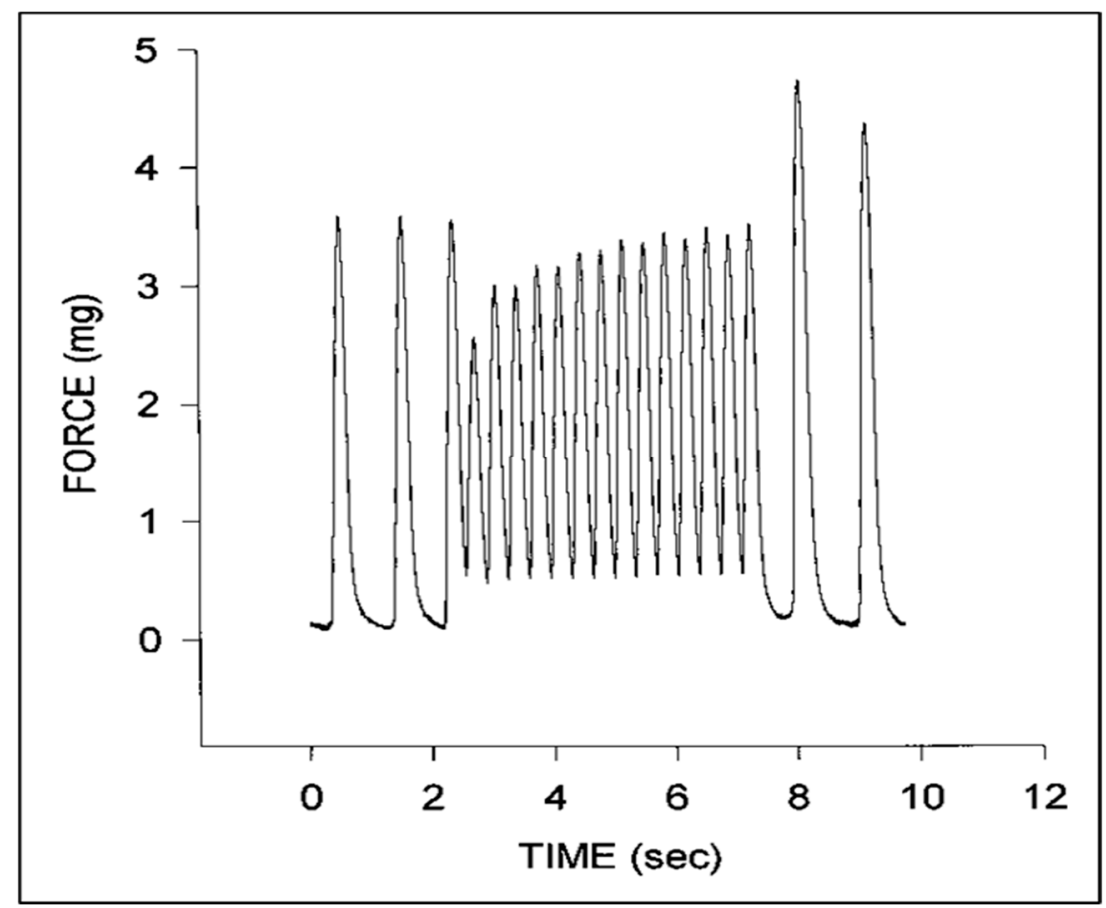

Figure 7. Representative force tracings for a stage 24 chick embryo myocardial specimen. Note the initial increase in diastolic force and decrease in systolic force at higher pacing rates that gradually increases with time and the increase in peak systolic force upon return to the intrinsic pacing rate. This was adapted with permission [123].

The correlation of high-resolution anatomic and hemodynamic data for the rapidly developing heart allowed computational models developed for the adult heart such as thick walled, pseudoelastic cylindrical shells with realistic activation patterns and estimated material properties [125-127] to 
be adapted and applied to the embryonic chick heart [128]. A poroelastic model with muscle activation and residual stress displayed heart-rate-dependent ventricular filling comparable to experimental data [129-131]. Initial epicardial strain measurements suggested isometric myofiber shortening [132,133], though expanded epicardial strain measurements identified the transition from isotropic to anisotropic myofiber shortening (Figure 8), consistent with trabecular expansion and compaction resulting in mature transmural fiber angle gradients (Figure 9) [8,97,134-136]. Advances in the application and refinement of 3D imaging methods, including magnetic resonance microscopy [137,138], optical coherence tomography (OCT [139-142]), and micro-CT [143], has allowed for the correlation of changes in dimensions with measures of blood velocity and the incorporation of these findings in computational models of the biomechanics of cardiac morphogenesis, including the process of cardiac looping [131,144].

A.

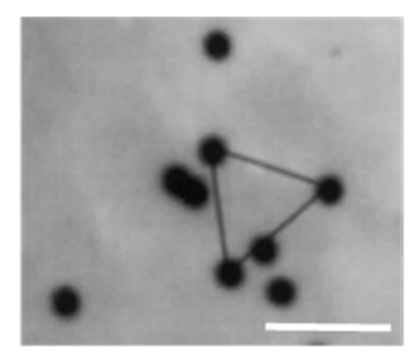

B.
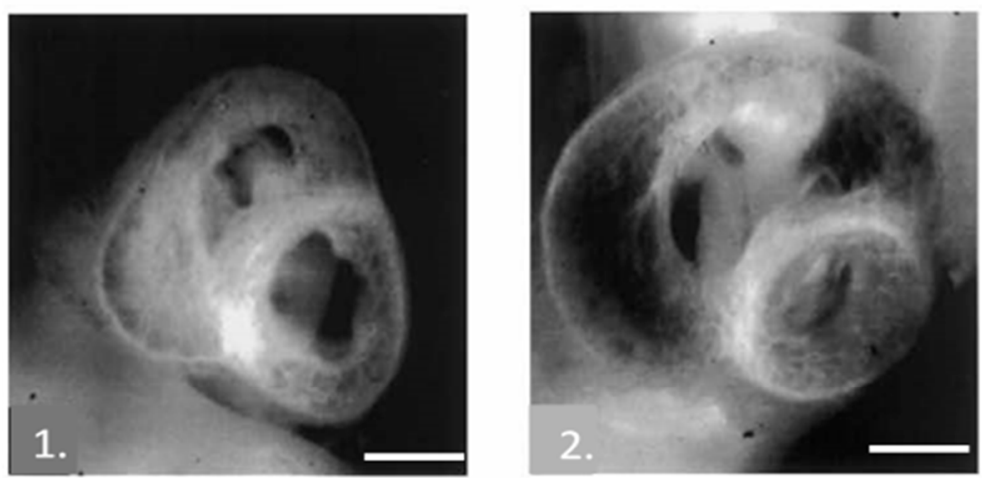

E.

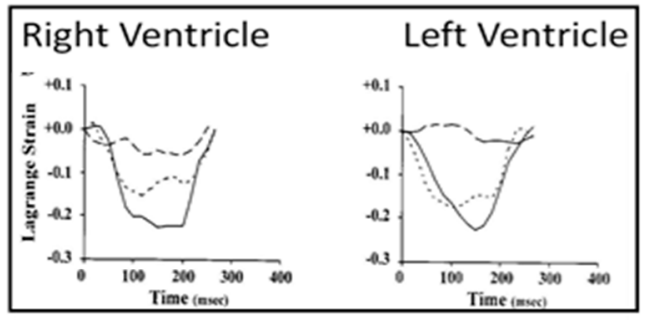

F.

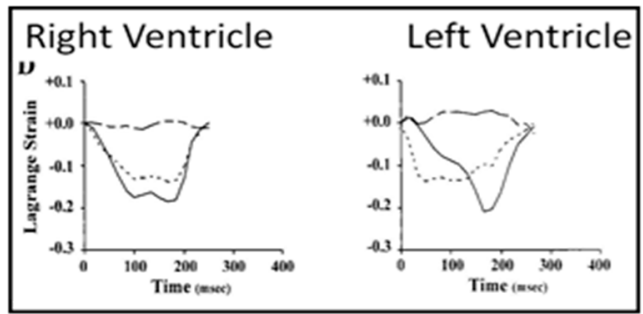

Figure 8. Right and left ventricular epicardial strains in normal and left heart hypoplasia chick embryos. (A) Representative video image of $10 \mu \mathrm{m}$ diameter microspheres attached to the left ventricular (LV) epicardium of a stage 24 chick embryo. Epicardial strains were measured by tracking the motion of microspheres in triangular arrays. Scale bar $=50 \mu \mathrm{m}$. (B) Representative midventricular transverse sections for stage 27 normal (1.) and left-atrial ligated (LAL) (2.) chick embryos. Note the obvious increase in right ventricular (RV) and decrease in LV dimensions. Scale bar $=1 \mathrm{~mm}$. (C) Representative developmental changes in strain-time curves for normal stage 21 chick ventricles; (D) stage 21 LAL chick ventricles; (E) stage 31 normal chick ventricles, and; (F) stage 31 LAL chick ventricles. Solid, broken, and dashed lines indicate epicardial circumferential, longitudinal, and shear strains, respectively. The $x$-axis is time (msec) and the $y$-axis is strain normalized to end-diastole. Note that from stage 21 to 31 , the strain patterns change from isotropic to RV- and LV-specific anisotropic patterns and that LAL strains at stage 31 markedly differ from normal embryos. This was adapted with permission [134]. 
A.

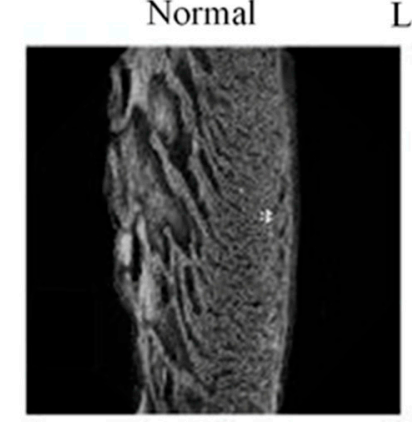

Left Atrial Ligation (LAL)

Conotruncal Band (CTB))

B.
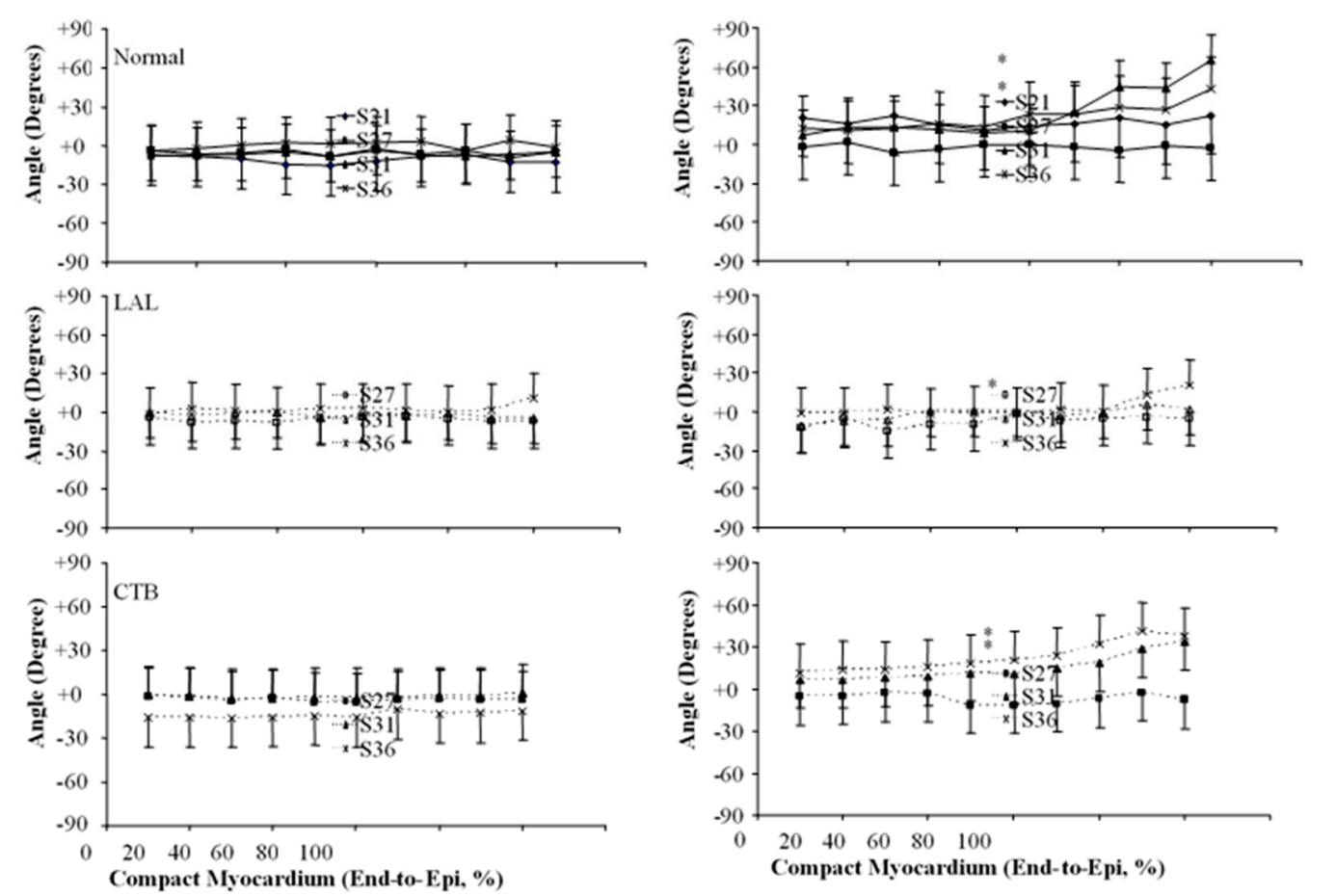

Figure 9. Three-dimensional myofiber architecture of the embryonic LV during normal development and altered mechanical loads. (A) Developmental change of the LV myocardial architecture in normal, left-atrial ligated (LAL), and conotruncal banded (CTB) embryos at stage 36. Scale bar $=500 \mu \mathrm{m}$. (B) Transmural myofiber angle distribution of the LV compact myocardium in normal, LAL, and CTB embryos. Data expressed as mean \pm SD. Horizontal axis represents transmural coordinate of compact myocardium from endocardium $(0 \%)$ to epicardium (100\%). Asterisk, $p<0.05$ by nonparametric ranking test vs. normal at the same developmental stage. This was adapted with permission [135].

Numerous research teams have quantified intracardiac biomechanical loading conditions (blood flow, 3D and 4D shear stresses, strains) during normal AV valve (Figure 10) [136,145-155], outflow tract [156-160], and aortic arch morphogenesis (Figure 11) [34,161-167]. The impact of altered biomechanical loading conditions on cardiac and vascular morphogenesis (Figure 12) has confirmed altered intracardiac blood flow as one etiology for CHD [135,165,168-175]. Increased ventricular loading associated with CT banding alters ventricular gene expression and mitral valve morphogenesis [176]. CT banding increased velocities altered conotruncal collagen content both upstream and downstream of the band along with changes in shear-flow responsive, extra-cellular matrix (ECM), and endothelial-mesenchymal transition (EMT)-related gene transcripts [174,177]. In vitro studies confirm the biomechanical regulation of outflow track cushion ECM kinetics [178]. Altered hemodynamics also impacts epicardial as well as intracardiac morphogenesis [179]. 
A.

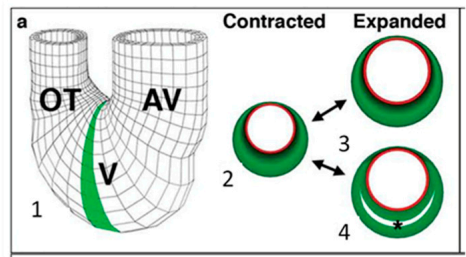

B.

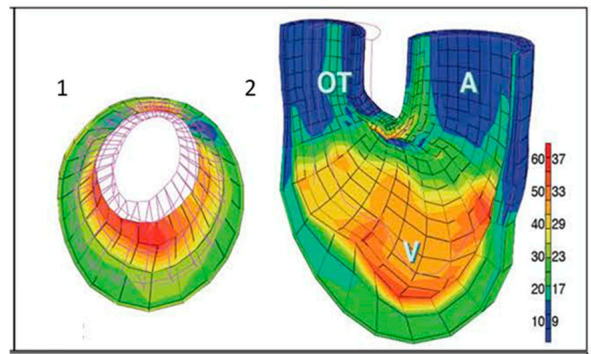

Figure 10. Computational modeling of embryonic heart wall strains. (A) Model and problem orientation. 1. Three-dimensional mesh diagram of tubular chick heart exterior with atrioventricular (AV) canal, ventricular (V) loop and outflow tract (OT) with the shaded 2D cross-sectional plane selected for further analysis; 2 . diagramed in the contracted state with a subendocardial layer (red) and muscle cross-sectional area (green). Two plausible expanded states are shown for a solid wall (3) or a wall with trabecular spaces (4). (B) Finite element modeling of stage 21 chick heart with a four-layer mesh shows greater strain (red) along inner layers at maximal expansion. 1. (A) Two-dimensional section across the ventricular loop; 2. (A) Three-dimensional global mesh oriented as in A1 with the anterior half removed to show interior surfaces. The scale shows the percentage elongation of initially unloaded elements along the left, with corresponding fractional shortening (\%) shown to the right. This was adapted with permission [136].

A.

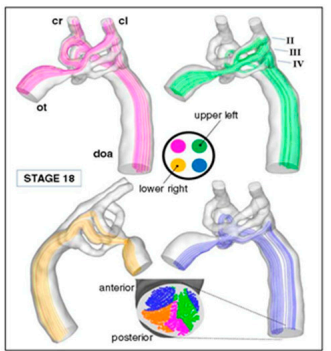

B.

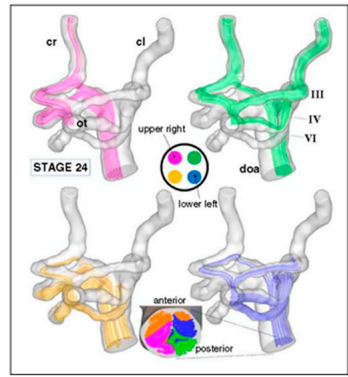

C.

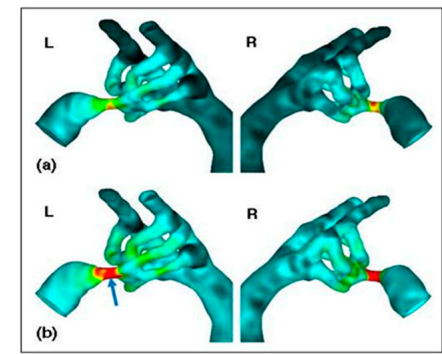

D.

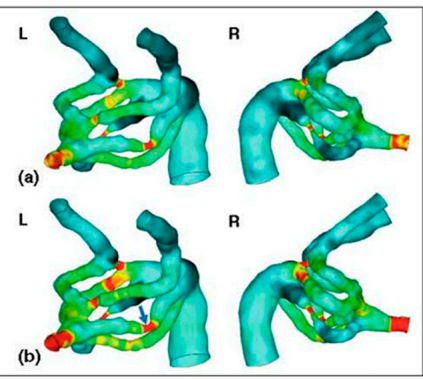

Figure 11. Aortic arch morphogenesis and flow modeling. (A) Representative mean flow path-lines using realistic geometries from micro-CT casts, fluorescent ink injections in a stage 18 chick embryo. Note that flow stream separation occurs through the aortic sac, arches, and dorsal aorta. (B) Representative mean flow path-lines using realistic geometries from micro-CT casts, fluorescent ink injections in a stage 24 chick embryo with similar flow stream separation. (C) Aortic sac and arch wall shear stress distributions at stage 18 for the left lateral (L) and right lateral (R) views. (D) Aortic sac and arch wall shear stress distributions at stage 24 . This was adapted with permission [161]. 
A.

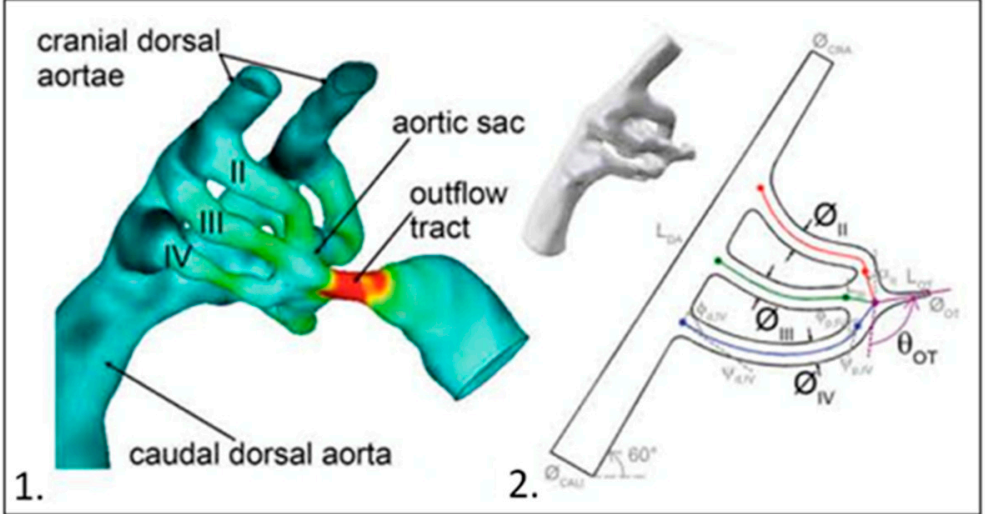

B.

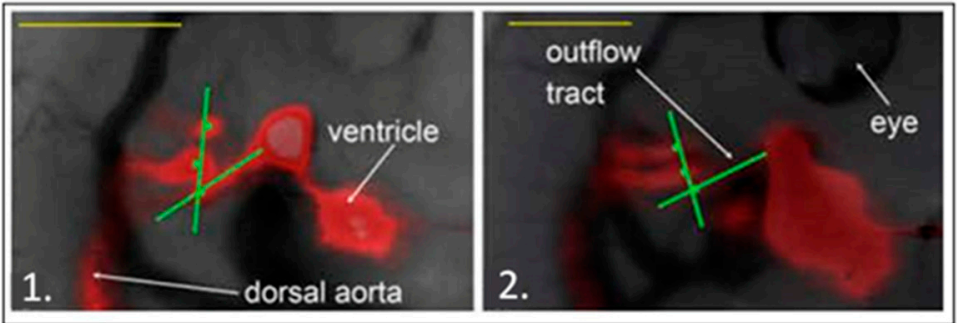

C.

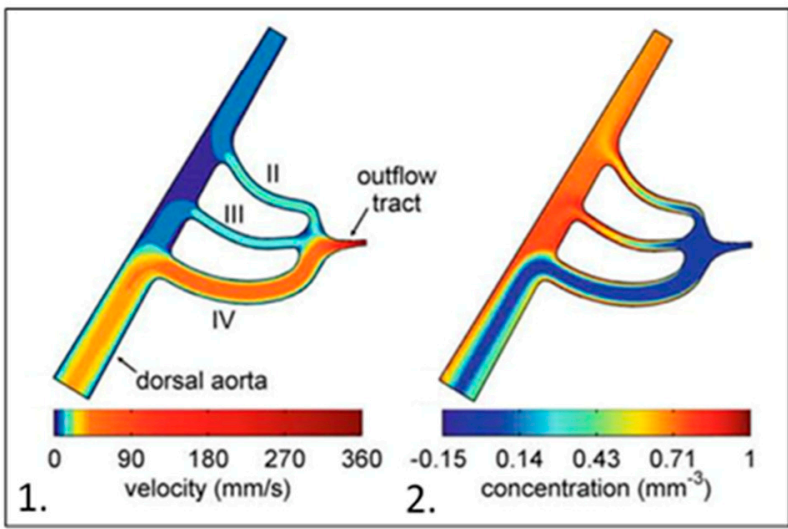

Figure 12. Computational hemodynamic optimization predicts embryonic chick aortic arch selection. (A) Three-dimensional polymeric cast of a stage 18 aortic sac and arches with color representing wall shear stress magnitudes (1.) and parameterized stage 18 right lateral aortic arch geometry (2.). (B) Representative fluorescent dye injections and angle measurements in stage 21 (1.) and stage 24 (2.) chick embryos. Scale bar $=1 \mathrm{~mm}$. (C) Power + diffusion optimization predicts the selection of the aortic arch IV though arches II and III remain patent for an outflow tract angle of $102^{\circ}$ and an energy/diffusion ratio of 1.85. This was adapted with permission [162].

\section{Chronic Interventional Models Investigate the Relationships between Embryonic Hemodynamics and Morphogenesis}

The chick embryo model is uniquely suited to investigate the impact of chronic interventions on structure-function relationships and the dependence of CV morphogenesis on a threshold and physiologic range of biomechanical loading. Early experiments to reduce ventricular filling suggested that mechanical load could regulate cardiac and vascular morphogenesis $[28,180]$. Experiments using nylon suture to create left-atrial ligation (LAL) redistribute intracardiac blood flow away from the developing left ventricle and produce left heart hypoplasia [181-183]. Careful perfusion-fixed histologic analysis using the Pexieder technique revealed disordered trabecular compaction in the developing left ventricle with a compensatory increase in right ventricular chamber dimensions [181]. Anatomic 
changes after LAL were associated with reduced myocyte proliferation in the LV compact and trabecular layers [182] and increased stiffness, in part due to microtubule accumulation [124]. Epicardial strain analysis confirmed altered myocardial deformation patterns after LAL with reduced LV longitudinal strain and enhance RV circumferential strain [134,135] as well as changes in regional passive stress-strain relations (Figure 9B) [135]. Progressive LV hypoplasia also occurs in the human fetus with aortic valve stenosis and hypoplastic left heart syndrome (HLHS) [184,185]. The embryonic chick LV after LAL displays disordered gene expression as well as endocardial fibroelastosis [186,187], which may be due, in part, to shear sensing by endocardial cilia [188]. The human heart displays altered gene expression in the setting of HLHS [189-191], though it is not clear if those changes in gene expression are causative or adaptive. Altered ventricular loading conditions have also been used to determine the relationship between mechanical load and the induction and maturation of the conducting fibers within the developing heart. Elegant pulse-chase, retroviral marking, optical mapping experiments documented the withdrawal of myocytes from proliferation at the tips of the embryonic ventricular trabeculae, forming the initial Purkinje fibers within the embryonic heart [192-194] with changes in myocardial activation patterns [30,68,195,196]. LAL also alters aortic arch morphogenesis [183] via changes in shear stress [164].

Altering venous return to the embryonic chick heart is another classic method to investigate the impact of altered mechanical loading conditions on ventricular and vascular morphogenesis. Initial studies confirmed that disrupting venous return by vitelline vein ligation (VVL) was sufficient to alter intracardiac blood flow patterns and aortic arch morphogenesis [27]. Unilateral VVL was then carefully investigated to visualized altered cardiac and arch blood flow patterns using ink injection [197,198] and particle velocimetry [147] and VVL produces a spectrum of CHD, including ventricular septal defects, semilunar valve abnormalities, double outlet right ventricle, and altered aortic arches [198,199]. Measurements of dorsal aortic hemodynamics [57,200,201] and ventricular function [202-205] after VVL confirmed changes in hemodynamic load, reduced ventricular contractility, and increased ventricular stiffness. VVL-induced changes in ventricular and aortic arch morphogenesis are associated with changes in the expression of shear-stress responsive genes [206-209], including high shear stress responsive Kruppel-like factor-2 (KLF-2) and Nitric Oxide Synthase-3 (NOS-3) and lower shear stress responsive Endothelin-1 (ET-1), which have been shown to be associated with CHD [209,210].

The embryonic heart has a contractile reserve to increase developed pressure in response to increased mechanical load (Figure 13) [22,98] and the impact of chronically increased ventricular loading conditions on embryonic ventricular morphogenesis and growth has been evaluated using a nylon suture to produce conotruncal (CT) constriction [29,211-214]. Following CT banding in the chick embryo, embryonic ventricular mass increases in response to chronically increased ventricular loading via myocyte proliferation rather than the hypertrophic response noted in the post-natal heart [181,214-217]. Careful histologic studies confirmed changes in both trabecular and compact myocardial structure [8,181], and transmural myofiber angles [135] and myofiber maturation [172]. RNA sequencing after CT banding has identified changes in myocardial gene expression, including transcripts in multiple metabolic and adaptive pathways [174,218]. CT banding results in changes in the morphometry and gene expression of the developing mitral valve [176] and the epicardium [179] and some of these changes may be reversible [219]. As mentioned in the discussion of computational models of cardiac morphogenesis and remodeling, chronic decreases and increases in mechanical loading conditions provided test conditions to validate and refine predictive models. 


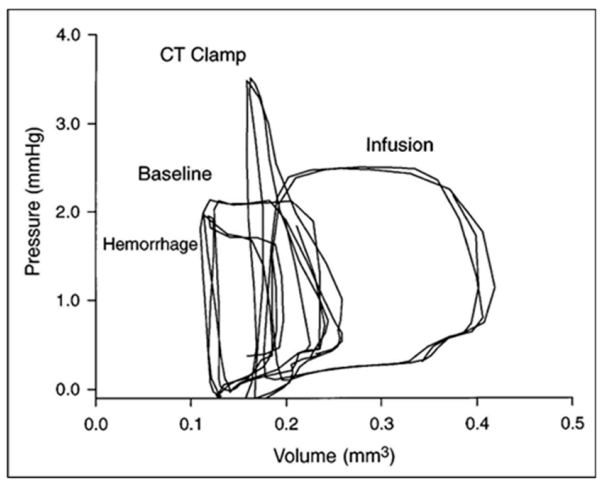

Figure 13. Ventricular-vascular uncoupling during acute conotruncal (CT) occlusion. Representative pressure-volume loops at baseline, during buffer infusion, and after CT clamp in a stage 21 chick embryo. Note the increased end-systolic pressure despite reduced stroke volume during CT clamp consistent with contractile reserve and only a modest increase in end-systolic pressure during infusion consistent with a curvilinear end-systolic PV relation. This was adapted with permission [98].

Experiments utilizing VVL, CTB, LAL, or unilateral vitelline arterial ligation (VAL) to alter intracardiac and aortic arch mechanical loading also highlight the adaptive responses of the developing embryonic vasculature $[113,164,202,220,221]$. The simultaneous measurement of dorsal aortic pressure and flow following VAL reveals an acute adaptive response to maintain pressure at the expense of blood flow [220] and chronic remodeling of the dorsal aorta resulting in increased stiffness, pulse-wave velocity, and vascular collagen content (Figure 14) [221]. More recent studies have confirmed a role for altered arterial mechanical loading on arterial cellular composition [41] relevant to the aortopathy noted in patients with bicuspid aortic valves and enlarged aortas [42].

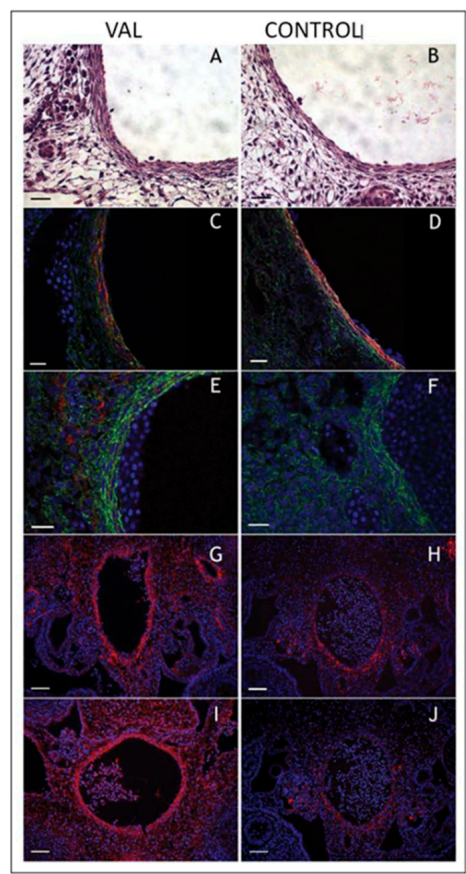

Figure 14. Increased arterial load via unilateral vitelline artery ligation (VAL) alters aortic structural properties. Representative images of $\operatorname{VAL}(\mathbf{A}, \mathbf{C}, \mathbf{E}, \mathbf{G}, \mathbf{I})$ and control $(\mathbf{B}, \mathbf{D}, \mathbf{F}, \mathbf{H}, \mathbf{J})$ dorsal aortas stained with hematoxylin and eosin $(\mathbf{A}, \mathbf{B})$, and antibodies against smooth muscle $\alpha$-actin $(\mathbf{C}, \mathbf{D})$, collagen type III $(\mathbf{E}, \mathbf{F})$, procollagen type I $(\mathbf{G}, \mathbf{H})$, and antibody M38 $(\mathbf{I}, \mathbf{J})$ show increased content in dorsal aorta and perivascular tissues in VAL embryos. Magnification is $\times 600$ and scale bars are $20 \mu \mathrm{m}$ for A-F, and $\times 200$ and $50 \mu \mathrm{m}$, respectively, for G-J. This was adapted with permission [221]. 
A transformative advance in our understanding of cardiac morphogenesis and the origins of CHD occurred following the observation that the ablation of small segments of neural crest at critical developmental windows resulted in a denervated avian heart [222] and, more importantly, in abnormal aortopulmonary septation and great vessel morphogenesis [223-225], which produced a spectrum of CHD including outlet ventricular septal defects, abnormal semilunar valves, and arch malformations typical for Type B interrupted aortic arch, tetralogy of Fallot, and Truncus Arteriosus. The direct measurement of dorsal aortic pressure and flow confirmed altered hemodynamics concurrent with altered morphogenesis [226], including an increased risk of non-survival in neural crest ablated embryos with altered ventricular function [227] and increased end-diastolic volumes suggesting decreased contractility [228]. Depressed ventricular function was also noted in the Pax3 mutant mouse that displays abnormal neural crest migration, CHD, and abnormal myofiber calcium kinetics [229-231]. Thus, the etiology of altered ventricular function following abnormal neural crest migration is likely multifactorial, including the effects of altered innervation, altered ion channel maturation and kinetics, and altered ventricular and vascular morphogenesis.

\section{Expanding Developmental Cardiovascular Biomechanics Paradigms in Model Systems}

Exploration of $\mathrm{CV}$ functional maturation and the relationships between function, biomechanics, and morphogenesis in mammalian embryos began with the adaptation of hemodynamic measurement techniques developed for the exposed chick embryo with novel methods to ensure normal maternal oxygenation during sedation, normal embryo temperature, maternal oxygenation, and undisturbed maternal-embryo coupling (Figure 15) [232-234]. Ultrasound proved very useful in quantifying basic measures of chamber dimensions, ventricular function, and blood flow velocities in normal mouse embryos [232,235-242], in embryos with trisomy 16 [243], and embryos exposed to maternal caffeine (Figure 16) [244,245]. Murine embryonic dorsal aortic flow velocity measurement revealed reduced diastolic forward flow consistent with increased murine placental resistance compared to similar stages in human development $[239,246-252]$ and confirmed the dependence of cardiac output on stage dependent normal heart rates and activation sequence [253] and the dependence of arch morphogenesis on genetic factors [254]. High-resolution ultrasound screening for abnormal mouse embryo CV function became a robust tool for identifying novel CHD models in genetic screens [255-258]. Additional rodent embryonic phenotyping imaging tools include magnetic resonance (MR) microscopy $[137,138,259]$ and OCT [141,142].

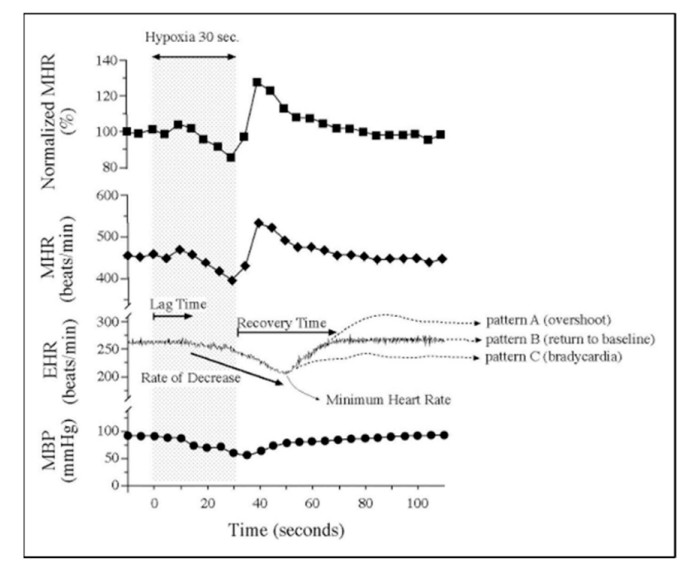

Figure 15. Embryonic vulnerability to acute maternal hypoxia. Representative maternal heart rate (MHR), embryonic heart rate (EHR), and maternal blood pressure (MBP) before, during, and after $30 \mathrm{~s}$ of maternal hypoxia via suspended ventilation. Lag time is defined as time from the onset of maternal hypoxia to the onset of bradycardia. Recovery time is defined as time from minimum EHR to return to baseline EHR. Patterns of EHR recovery are defined as (A) post-hypoxia tachycardia; (B) post-hypoxia return to baseline; and (C) post-hypoxia persistent bradycardia. Adapted with permission [234]. 
A.

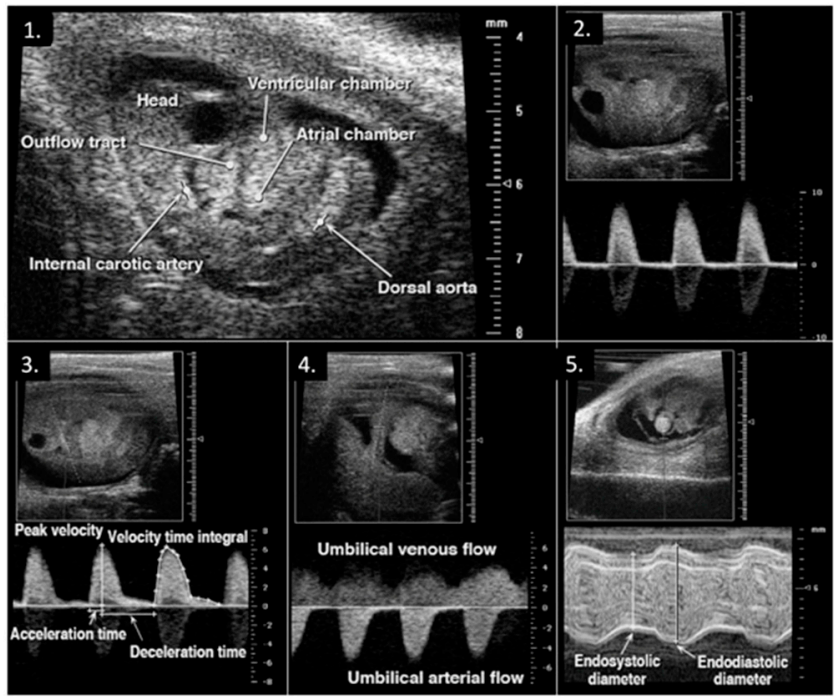

B.

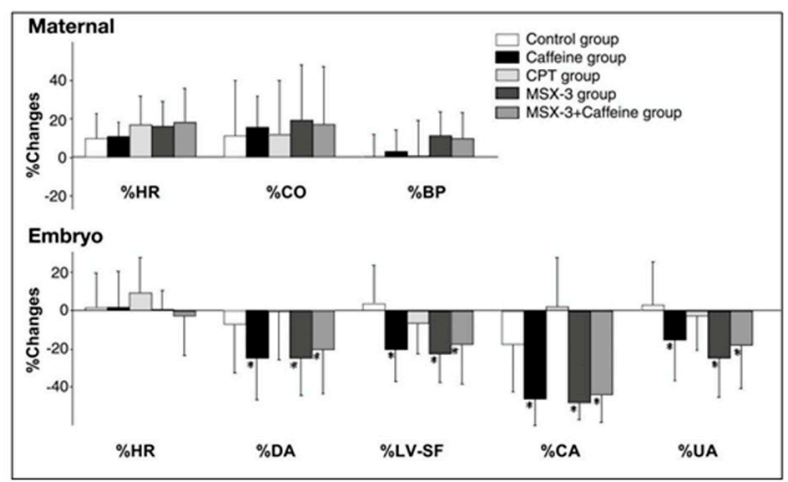

Figure 16. Modest maternal caffeine exposure affects murine embryonic cardiovascular function. (A) Representative in vivo high-frequency echocardiogram images and pulsed-Doppler waveforms from CD-1 mouse embryos. 1. B-mode image of an embryonic day (ED) 10.5 embryo. Arrowheads indicate velocity sampling locations; 2 . dorsal aortic pulsed-Doppler velocity waveforms at ED 12.5. The scale on the right denotes Doppler velocity $(\mathrm{cm} / \mathrm{s}) ; 3$. internal carotid arterial pulsed-Doppler velocity waveforms at ED 12.5; 4 . Umbilical arterial pulsed-Doppler velocity waveforms at ED 11.5; 5. M-mode image of an ED 11.5 embryonic LV planimetered to determine end-diastolic and end-systolic dimensions. This was adapted with permission (Momoi et al. 2007). (B) Representative changes in maternal and embryo hemodynamics $30 \mathrm{~min}$ after maternal treatment with caffeine $(10 \mathrm{mg} / \mathrm{kg})$, adenosine $A_{1}$ selective antagonist 8-cyclopentyl-1,3-dimethylxanthine (CPT) $(4.8 \mathrm{mg} / \mathrm{kg})$, or adenosine $\mathrm{A}_{2 \mathrm{~A}}$ selective antagonist MSX-3 (3.0 mg/kg). Maternal HR, cardiac output (CO), and systolic blood pressure (BP) did not change from baseline in response to any treatment (top). MSX-3 mirrored the caffeine effects on embryonic hemodynamics (bottom), and no additive effects occurred by concurrent treatment of caffeine and MSX-3, suggesting that the negative CV effects of caffeine on embryonic hemodynamics occur via the adenosine $\mathrm{A}_{2 \mathrm{~A}}$ receptor. The values are mean $\pm \mathrm{SD}$ and represent changes from baseline. ${ }^{*} p<0.05$ vs. the control (ANOVA). This was adapted with permission [245].

The rapidly developing and transparent zebrafish embryo provides another unique and robust experimental model to test genetics-structure-function CV morphogenesis and adaptation paradigms $[40,260]$. Similar to avian and murine embryos, there is a linear log-log relationship between ventricular and body weight and both peak ventricular and aortic systolic pressure increase geometrically during CV morphogenesis (Figure 17A) [261]. Similar to avian and murine embryos [21,232], the zebrafish embryonic heart has a contractile bulbus arteriousus that remodels into a non-contracting great vessel. High-resolution particle velocimetry imaging revealed intracardiac blood flow patterns consistent with the shear stresses predicted from studies in chick embryos [262], 
and similar to the chick embryo, disrupting normal blood flow patterns resulted in abnormal cardiac structure, including the failure of looping, development of the bulbus, and the failure of cardiac chamber expansion and growth; and reduced cardiac function [262]. Altered intracardiac shear stress results in abnormal zebrafish embryo endocardial cushion development [263], and blood cell movement within the sequentially contracting and relaxing zebrafish embryo heart tube suggested the presence of ventricular suction [264], which depends on the coordinated apposition and then relaxation of inlet and outlet cushions during the cardiac cycle, similar to observations made in the chick embryo almost 60 years earlier [12]. High-resolution 3D imaging of the transparent zebrafish embryo heart [265] as well as standard edge-detection methods [266] showed a negative chronotropic response to temperature and positive inotropic response to norepinephrine similar to chick [104] and rat [74] embryos. As with the chick and mouse embryo models, the availability of high-resolution imaging and hemodynamic instrumentation along with the ability to instrument the zebrafish embryo during rapid growth and morphogenesis led to a range of excellent studies related to the hemodynamic regulation of morphogenesis in normal zebrafish embryos (Figure 17B,C) [267-278], the impact of numerous molecular pathways on zebrafish embryo cardiac morphogenesis and function $[167,279,280]$, and the inflammatory cellular response of the zebrafish embryonic heart to thermal injury [281]. Many of the zebrafish studies have validated paradigms developed in the chick embryo, including function-structure relationships, the importance of finely-tuned mechanical loading forces on valve and chamber morphogenesis, the important role of the neural crest in zebrafish cardiac morphogenesis [282], and the role of miRNAs in cardiac morphogenesis and function $[283,284]$.

A.

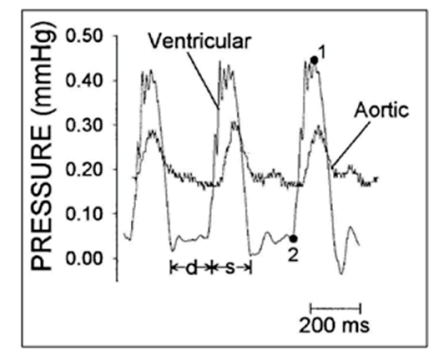

B.
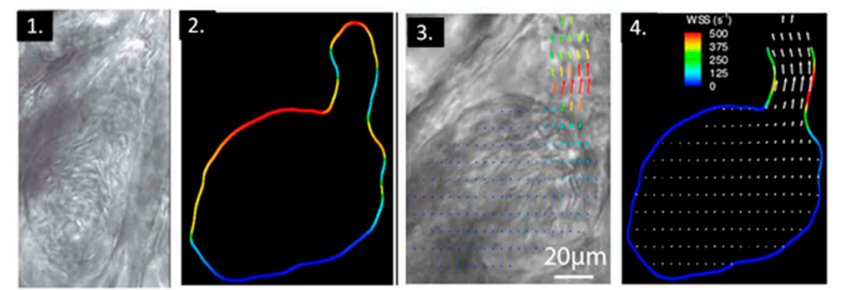

C.

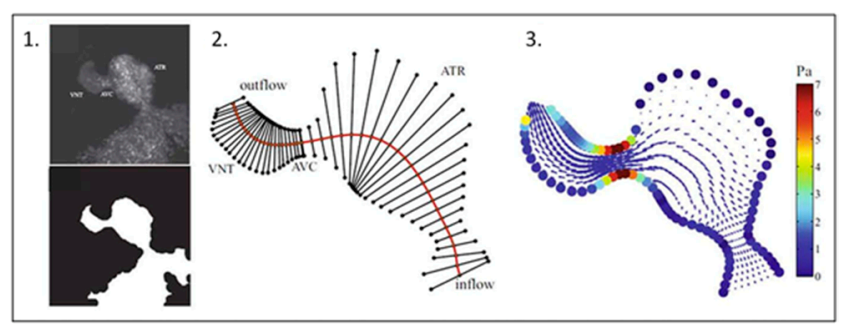

Figure 17. Zebrafish embryo hemodynamics. (A) Representative ventricular and dorsal aortic pressure waveforms of a 5-day post-fertilization Zebrafish. D-diastolic and s-systolic time intervals, 1-ventricular peak pressure and 2-ventricular end-diastolic pressure. Scale bar $=200 \mathrm{msec}$. This was adapted with permission [261]. (B) Velocity and wall shear stress (WSS) measurements via digital particle image velocimetry for Zebrafish embryos. 1. Brightfield image for the ventricle of a 4-dpf Zebrafish embryo; 2. vessel boundaries are determined as the limits of cell movements; 3 . velocity vectors for cell 
movements; 4 . calculated wall shear rates overlaid with velocity vectors. This was adapted with permission [275]. (C) Coupled confocal imaging and computational modeling approach for Zebrafish heart hemodynamics. 1. Segmentation of the heart wall from maximum intensity projection of a confocal scan for a 48-hpf embryo; 2 . cross-section segments through the heart and their intersection points with the wall. ATR, atrium; VNT, ventricle; AVC, atrioventricular canal; 3 . velocity vectors and WSS levels from the in silico computational fluid dynamics (CFD) model at peak systole. Adapted with permission [275].

Ultrasound studies of the developing embryonic heart revealed a progressive increase in intracardiac and aortic velocities at morphologic stages similar to avian and murine embryos [285-287]. Maternal diabetes, which is associated with more than twice the risk for CHD [50], was found to be associated with altered fetal heart rates and increased umbilical arterial velocity variability in the setting of [285].

\section{Future Horizons}

After more than a century of investigation of the relationships between structure and function during CV morphogenesis, much has been revealed from the macro-scale level of chamber dimensions and developed pressures and flows to the micro-scale level molecular regulation of cell lineage expansion, morphogenesis, and adaptation during normal heart morphogenesis and in response to altered trajectories $[48,59,288]$. Continued multi-scale studies using a broad range of model systems and single-cell genetics will provide mechanistic explanations for the pathogenic origins of CHD described over more than 3 decades ago $[48,49]$. The identification of epigenetic and genetic factors associated with CHD [289-295] create the opportunity for novel strategies to reduce the occurrence and/or the severity of CHD. One critical barrier to the long-term treatment of congenital heart disease and to cardiac repair and regeneration is the withdrawal of cardiomyocytes from self-renewal in the post-natal human heart. The identification of the molecular systems that repress cardiomyocyte proliferation will create a novel opportunity for reparative strategies. Innovative tissue engineering [296] and stem cell implantation strategies $[297,298]$ are also emerging for use during congenital heart surgery. Based on the spectacular range of model systems, experimental techniques, and computational methods, it is clear that where we go from here will be both fascinating and translational for many decades to come.

Funding: The research described was supported by a broad range of non-profit institutions, foundations, and government agencies as identified on individual publications.

Acknowledgments: The findings described were made possible through the tireless and inspired efforts of hundreds of students, residents, fellows, post-doctoral scientists, clinician-investigators; and with the collaborative efforts of our global community of innovative scientists.

Conflicts of Interest: The authors declare no financial of scientific conflicts of interest.

\section{References}

1. Patten, B.M. The Early Embryology of The Chick; P. Blakiston's Son \& Co: Philadelphia, PA, USA, 1920; p. 228.

2. Hamburger, V.; Hamilton, H.L. A series of normal stages in the development of the chick embryo. J. Morphol. 1951, 88, 49-92. [CrossRef] [PubMed]

3. Romanoff, A.L. The Avian Embryo; Structural and Functional Development; Macmillan: New York, NY, USA, 1960.

4. Manasek, F.J. Embryonic development of the heart. I. A light and electron microscopic study of myocardial development in the early chick embryo. J. Morphol. 1968, 125, 329-365. [CrossRef]

5. Sissman, N.J. Developmental landmarks in cardiac morphogenesis: Comparative chronology. Am. J. Cardiol. 1970, 25, 141-148. [CrossRef]

6. Pexieder, T. Mechanisms of Cardiac Morphogenesis and Teratogenesis; Raven Press: New York, NY, USA, 1981.

7. Sedmera, D.; Pexieder, T.; Hu, N.; Clark, E.B. Developmental changes in the myocardial architecture of the chick. Anat. Rec. 1997, 248, 421-432. [CrossRef] 
8. Sedmera, D.; Pexieder, T.; Vuillemin, M.; Thompson, R.P.; Anderson, R.H. Developmental patterning of the myocardium. Anat. Rec. 2000, 258, 319-337. [CrossRef]

9. Szepsenwol, J. Electrical excitability and spontaneous activity in explants of skeletal and heart muscle of chick embryos. Anat. Rec. 1947, 98, 67-85. [CrossRef]

10. Dufourm, J.J.; Posternak, O.J.M. Chronotropic effects of acetylcholine on the chick embryo heart. Helv. Physiol. Pharmacol. Acta (French) 1960, 18, 563-580.

11. DeHaan, R.L. Development of pacemaker tissue in the embryonic heart. Ann. NY Acad. Sci. 1965, 127, 7-18. [CrossRef]

12. Barry, A. The functional significance of the cardiac jelly in the tubular heart of the chick embryo. Anat. Rec. 1948, 102, 289-298. [CrossRef]

13. Patten, B.M.; Kramer, T.C.; Barry, A. Valvular action in the embryonic chick heart by localized apposition of endocardial masses. Anat. Rec. 1948, 102, 299-311. [CrossRef] [PubMed]

14. Hughes, A.F.W. The heart output of the chick embryo. J. R. Microsc. Soc. 1949, 69, 145-152. [CrossRef] [PubMed]

15. Jaffee, O.C. Hemodynamic factors in the development of the chick embryo heart. Anat. Rec. 1965, 151, 69-75. [CrossRef]

16. Jaffee, O.C. Hemodynamics and cardiogenesis: The effects of physiologic factors on cardiac development. Birth Defects Orig. Artic. Ser. 1978, 14, 393-404. [PubMed]

17. Boucek, R.J.; Murphy, W.P., Jr.; Paff, G.H. Electrical and mechanical properties of chick embryo heart chambers. Circ. Res. 1959, 7, 787-793. [CrossRef]

18. De La Cruz, M.V.; Campillo, S.C.; Munoz Armas, U.S.; Pascual, C.A.; Zamundo, B.R. Congenital heart disease and other malformations produced by Influenza A virus and allantoic fluid in the chick embryo. Circ. Res. 1963, 13, 572-579. [CrossRef] [PubMed]

19. Paff, G.H.; Boucek, R.J.; Klopfenstein, H.S. Experimental heart-block in the chick embryo. Anat. Rec. 1964, 149, 217-223. [CrossRef]

20. Van Mierop, L.H.; Bertuch, C.J., Jr. Development of arterial blood pressure in the chick embryo. Am. J. Physiol. 1967, 212, 43-48. [CrossRef]

21. Faber, J.J. Mechanical function of the septating embryonic heart. Am. J. Physiol. 1968, 214, 475-481. [CrossRef]

22. Faber, J.J.; Green, T.J.; Thornburg, K.L. Embryonic stroke volume and cardiac output in the chick. Dev. Biol. 1974, 41, 14-21. [CrossRef]

23. Manasek, F.J.; Monroe, R.G. Early cardiac morphogenesis is independent of function. Dev. Biol. 1972, 27, 584-588. [CrossRef]

24. Hill, L.; Azuma, Y. Blood pressure in the two-three-day chick embryo. J. Physiol. 1927, 62, 27-28.

25. Hughes, A.F.W. The blood pressure of the chick embryo during development. J. Exp. Biol. 1942, 19, $232-237$.

26. Paff, G.H.; Boucek, R.J.; Gutten, G.S. Ventricular blood pressure and competency of valves in the early embryonic chick heart. Anat. Rec. 1965, 151, 119-123. [CrossRef] [PubMed]

27. Rychter, Z.; Lemez, L. Changes in localization in aortic arches of laminar blood streams of main venous trunks to heart after exclusion of vitelline vessels on second day of incubation. Fed. Proc. Transl. Suppl. 1965, $24,815-820$.

28. Dbalý, J.; Rychter, Z. The vascular system of the chick embryo. XVII. The development of branching of the coronary arteries in the chick embryos with experimentally induced left-half heart hypoplasy. Folia. Morphol. (Praha) 1967, 15, 358-368. [PubMed]

29. Gessner, I.H. Cardiovascular anomalies resulting from manipulating the truncoconal region of the early chick embryo heart. Birth Defects Orig. Art. Ser. 1978, 14, 405-422. [PubMed]

30. Gourdie, R.G.; Kubalak, S.; Mikawa, T. Conducting the embryonic heart: Orchestrating development of specialized cardiac tissues. Trends Cardiovasc. Med. 1999, 9, 18-26. [CrossRef]

31. Monsoro-Burq, A.H.; Levin, M. Avian models and the study of invariant asymmetry: How the chicken and the egg taught us to tell right from left. Int. J. Dev. Biol. 2018, 62, 63-77. [CrossRef]

32. Sylva, M.; van den Hoff, M.J.; Moorman, A.F. Development of the human heart. Am. J. Med. Genet. A. 2014, 164, 1347-1371. [CrossRef]

33. Tazawa, H.; Akiyama, R.; Moriya, K. Development of cardiac rhythm in birds. Comp. Biochem. Physiol. A. Mol. Integr. Physiol. 2002, 123, 675-689. [CrossRef] 
34. Courchaine, K.; Rykiel, G.; Rugonyi, S. Influence of blood flow on cardiac development. Prog. Biophys. Mol. Biol. 2018, 137, 95-110. [CrossRef]

35. Xavier-Neto, J.; Sousa Costa, Â.M.; Figueira, A.C.; Caiaffa, C.D.; Amaral, F.N.; Peres, L.M.; da Silva, B.S.; Santos, L.N.; Moise, A.R.; Castillo, H.A. Signaling through retinoic acid receptors in cardiac development: Doing the right things at the right times. Biochim. Biophys. Acta 2015, 1849, 94-111. [CrossRef] [PubMed]

36. Meilhac, S.M.; Buckingham, M.E. The deployment of cell lineages that form the mammalian heart. Nat. Rev. Cardiol. 2018, 15, 705-724. [CrossRef] [PubMed]

37. MacGrogan, D.; Münch, J.; de la Pompa, J.L. Notch and interacting signalling pathways in cardiac development, disease, and regeneration. Nat. Rev. Cardiol. 2018, 15, 685-704. [CrossRef] [PubMed]

38. Lescroart, F.; Zaffran, S. Hox and Tale transcription factors in heart development and disease. Int. J. Dev. Biol. 2018, 62, 837-846. [CrossRef]

39. Duncan, A.R.; Khokha, M.K. Xenopus as a model organism for birth defects-Congenital heart disease and heterotaxy. Semin. Cell Dev. Biol. 2016, 51, 73-79. [CrossRef]

40. Warren, K.S.; Fishman, M.C. "Physiological genomics": Mutant screens in zebrafish. Am. J. Physiol. 1998, 275, 1-7. [CrossRef]

41. Espinosa, M.G.; Taber, L.A.; Wagenseil, J.E. Reduced embryonic blood flow impacts extracellular matrix deposition in the maturing aorta. Dev. Dyn. 2018, 247, 914-923. [CrossRef]

42. Krishnamurthy, V.K.; Godby, R.C.; Liu, G.R.; Smith, J.M.; Hiratzka, L.F.; Narmoneva, D.A.; Hinton, R.B. Review of molecular and mechanical interactions in the aortic valve and aorta: Implications for the shared pathogenesis of aortic valve disease and aortopathy. J. Cardiovasc. Transl. Res. 2014, 7, 823-846. [CrossRef]

43. Karunamuni, G.H.; Ma, P.; Gu, S.; Rollins, A.M.; Jenkins, M.W.; Watanabe, M. Connecting teratogen-induced congenital heart defects to neural crest cells and their effect on cardiac function. Birth Defects Res. C. Embryo Today. 2014, 102, 227-250. [CrossRef]

44. Go, A.S.; Mozaffarian, D.; Roger, V.L.; Benjamin, E.J.; Berry, J.D.; Borden, W.B.; Bravata, D.M.; Dai, S.; Ford, E.S.; Fox, C.S.; et al. Heart disease and stroke statistics-2013 update: A report from the American Heart Association. Circulation 2013, 127, 6-245. [CrossRef]

45. DeHaan, R.L. Development of form in the embryonic heart. An experimental approach. Circulation 1967, 35, 821-833. [CrossRef]

46. Hoffman, J.I. Natural history of congenital heart disease. Problems in its assessment with special reference to ventricular septal defects. Circulation 1968, 37, 97-125. [CrossRef] [PubMed]

47. Neill, C.A. Genetic aspects of congenital heart disease. In Heart Disease in Infants, Children, and Adolescents; Moss, A.J., Adams, F.H., Eds.; Williams and Wilkins: Baltimore, MD, USA, 1968; pp. 36-46.

48. Clark, E.B. Mechanisms in the pathogenesis of congenital heart defects. In The Genetics of Cardiovascular Disease; Pierpont, M.E., Moller, J., Eds.; Martinuus-Nijoff: Boston, MA, USA, 1986; pp. 3-11.

49. Clark, E.B. Pathogenetic mechanisms of congenital cardiovascular malformations revisited. Semin. Perinatol. 1996, 20, 465-472. [CrossRef]

50. Ferencz, C. Congenital heart disease: An epidemiologic and teratologic challenge. In Perspectives in Pediatric Cardiology; Vol. 4; Epidemiology of Congenital Heart Disease: The Baltimore-Washington Infant Study 1981-1989; Futura Publishing: Mount Kisco, NY, USA, 1993; pp. 1-16.

51. Clark, E.B. Cardiac embryology. Its relevance to congenital heart disease. Am. J. Dis. Child. 1986, 140, 41-44. [CrossRef] [PubMed]

52. Gittenberger-de Groot, A.C.; Bartelings, M.M.; Deruiter, M.C.; Poelmann, R.E. Basics of cardiac development for the understanding of congenital heart malformations. Pediatr. Res. 2005, 57, 169-176. [CrossRef] [PubMed]

53. Clark, E.B.; Hu, N. Developmental hemodynamic changes in the chick embryo from stage 18 to 27. Circ. Res. 1982, 51, 810-815.

54. Clark, E.B.; Hu, N.; Dummett, J.L.; Vandekieft, G.K.; Olson, C.; Tomanek, R. Ventricular function and morphology in chick embryo from stages 18 to 29. Am. J. Physiol. 1986, 250, 407-413.

55. Hu, N.; Clark, E.B. Hemodynamics of the stage 12 to stage 29 chick embryo. Circ. Res. 1989, 65, $1665-1670$. [CrossRef] [PubMed]

56. Hu, N.; Connuck, D.M.; Keller, B.B.; Clark, E.B. Diastolic filling characteristics in the stage 12 to 27 chick embryo ventricle. Pediatr. Res. 1991, 29, 334-347. [CrossRef] [PubMed] 
57. Broekhuizen, M.L.; Mast, F.; Struijk, P.C.; van der Bie, W.; Mulder, P.G.; Gittenberger-de Groot, A.C.; Wladimiroff, J.W. Hemodynamic parameters of stage 20 to stage 35 chick embryo. Pediatr. Res. 1993, 34, 44-46. [CrossRef] [PubMed]

58. Ursem, N.T.; Struijk, P.C.; Poelmann, R.E.; Gittenberger-De Groot, A.C.; Wladimiroff, J.W. Dorsal aortic flow velocity in chick embryos of stage 16 to 28. Ultrasound Med. Bio. 2001, 27, 919-924. [CrossRef]

59. Burggren, W.W.; Keller, B.B. (Eds.) Development of Cardiovascular Systems: Molecules to Organisms; Cambridge University Press: New York, NY, USA, 1998.

60. Keller, B.B.; Liu, L.J.; Tinney, J.P.; Tobita, K. Cardiovascular developmental insights from embryos. Ann. Ny Acad. Sci. 2007, 100, 1399-1401. [CrossRef] [PubMed]

61. Pekkan, K.; Keller, B.B. Fetal and embryonic hemodynamics: Developmental fetal cardiovascular biomechanics in the 21st century: Another tipping point. Cardiovasc. Eng. Technol. 2013, 4, $231-233$. [CrossRef] [PubMed]

62. Kowalski, W.J.; Pekkan, K.; Tinney, J.P.; Keller, B.B. Investigating developmental cardiovascular biomechanics and the origins of congenital heart defects. Front. Biophys. 2014, 5, 4-8.

63. Voorhees, A.P.; Han, H.C. Biomechanics of Cardiac Function. Compr. Physiol. 2015, 5, 1623-1644.

64. Poelmann, R.E.; Gittenberger-de Groot, A.C. Hemodynamics in Cardiac Development. J. Cardiovasc. Dev. Dis. 2018, 5, 54. [CrossRef]

65. Wispé, J.; Hu, N.; Clark, E.B. Effect of environmental hypothermia on dorsal aortic blood flow in the chick embryo, stages 18 to 24. Pediatr. Res. 1983, 17, 945-948.

66. Nakazawa, M.; Clark, E.B.; Hu, N.; Wispé, J. Effect of environmental hypothermia on vitelline artery blood pressure and vascular resistance in the stage 18, 21, and 24 chick embryo. Pediatr. Res. 1985, 19, 651-654. [CrossRef] [PubMed]

67. Dunnigan, A.; Hu, N.; Benson, D.W., Jr.; Clark, E.B. Effect of heart rate increase on dorsal aortic flow in the stage 24 chick embryo. Pediatr. Res. 1987, 22, 442-444. [CrossRef]

68. Benson, D.W., Jr.; Hughes, S.F.; Hu, N.; Clark, E.B. Effect of heart rate increase on dorsal aortic flow before and after volume loading in the stage 24 chick embryo. Pediatr. Res. 1989, 26, 438-441. [CrossRef] [PubMed]

69. Sedmera, D.; Wessels, A.; Trusk, T.C.; Thompson, R.P.; Hewett, K.W.; Gourdie, R.G. Changes in activation sequence of embryonic chick atria correlate with developing myocardial architecture. Am. J. Physiol. 2006, 291, 1646-1652. [CrossRef] [PubMed]

70. Wagman, A.J.; Hu, N.; Clark, E.B. Effect of changes in circulating blood volume on cardiac output and arterial and ventricular blood pressure in the stage 18, 24, and 29 chick embryo. Circ. Res. 1990, 67, 187-192. [CrossRef]

71. Ostádal, B.; Rychterová, V.; Rychter, Z. Isoproterenol-induced necrotic lesions of embryonic heart tissue. Recent Adv. Stud. Cardiac Struct. Metab. 1975, 6, 453-459.

72. Hawkins, J.A.; Hu, N.; Clark, E.B. Effect of caffeine on cardiovascular function in the stage 24 chick embryo. Dev. Pharm. 1984, 7, 334-343. [CrossRef] [PubMed]

73. Clark, E.B.; Hu, N.; Turner, D.R.; Litter, J.E.; Hansen, J. Effect of chronic verapamil treatment on ventricular function and growth in chick embryos. Am. J. Physiol. 1991, 261, 166-171. [CrossRef]

74. Nakazawa, M.; Morishima, M.; Tomita, H.; Tomita, S.M.; Kajio, F. Hemodynamics and ventricular function in the day-12 rat embryo: Basic characteristics and the responses to cardiovascular drugs. Pediatr. Res. 1995, 37, 117-123. [CrossRef]

75. Hu, N.; Hansen, A.L.; Clark, E.B.; Keller, B.B. Effect of atrial natriuretic peptide on diastolic filling in the stage 21 chick embryo. Pediatr. Res. 1995, 37, 465-468. [CrossRef]

76. Sedmera, D.; Pexieder, T.; Hu, N.; Clark, E.B. A quantitative study of the ventricular myoarchitecture in the stage 21-29 chick embryo following decreased loading. Eur. J. Morphol. 1998, 36, 105-119. [CrossRef] [PubMed]

77. Tenthorey, D.; De Ribaupierre, Y.; Kucera, P.; Raddatz, E. Effects of verapamil and ryanodine on activity of the embryonic chick heart during anoxia and reoxygenation. J. Cardiovasc. Pharm. 1998, 31, 195-202. [CrossRef]

78. Wojtczak, J.A. The hemodynamic effects of halothane and isoflurane in chick embryo. Anesth. Analg. 2000, 90, 1331-1335. [CrossRef] [PubMed]

79. Sharma, S.K.; Lucitti, J.L.; Nordman, C.; Tinney, J.P.; Tobita, K.; Keller, B.B. Impact of hypoxia on early chick embryo growth and cardiovascular function. Pediatr. Res. 2006, 59, 116-120. [CrossRef] [PubMed] 
80. Clark, E.B.; Hu, N.; Dooley, J.B. The effect of isoproterenol on cardiovascular function in the stage 24 chick embryo. Teratology 1985, 31, 41-47. [CrossRef] [PubMed]

81. Pappano, A.J. Ontogenetic development of autonomic neuroeffector transmission and transmitter reactivity in embryonic and fetal hearts. Pharm. Rev. 1977, 29, 3-33. [PubMed]

82. Suga, H.; Sagawa, K.; Shoukas, A.A. Load independence of the instantaneous pressure-volume ratio of the canine left ventricle and effects of epinephrine and heart rate on the ratio. Circ. Res. 1973, 32, 314-322. [CrossRef] [PubMed]

83. Sagawa, K.; Suga, H.; Shoukas, A.A.; Bakalar, K.M. End-systolic pressure/volume ratio: A new index of ventricular contractility. Am. J. Cardiol. 1977, 40, 748-753. [CrossRef]

84. Khalafbeigui, F.; Suga, H.; Sagawa, K. Left ventricular systolic pressure-volume area correlates with oxygen consumption. Am. J Physiol. 1979, 237, 566-569. [CrossRef]

85. Kass, D.A.; Yamazaki, T.; Burkhoff, D.; Maughan, W.L.; Sagawa, K. Determination of left ventricular end-systolic pressure-volume relationships by the conductance (volume) catheter technique. Circulation 1986, 73, 586-595. [CrossRef]

86. Kass, D.A.; Maughan, W.L.; Guo, Z.M.; Kono, A.; Sunagawa, K.; Sagawa, K. Comparative influence of load versus inotropic states on indexes of ventricular contractility: Experimental and theoretical analysis based on pressure-volume relationships. Circulation. 1987, 76, 1422-1436. [CrossRef]

87. Maughan, W.L.; Sunagawa, K.; Burkhoff, D.; Sagawa, K. Effect of arterial impedance changes on the end-systolic pressure-volume relation. Circ. Res. 1984, 54, 595-602. [CrossRef]

88. Sunagawa, K.; Sagawa, K.; Maughan, W.L. Ventricular interaction with the loading system. Ann. Biomed. Eng. 1984, 12, 163-189. [CrossRef] [PubMed]

89. Sunagawa, K.; Maughan, W.L.; Sagawa, K. Optimal arterial resistance for the maximal stroke work studied in isolated canine left ventricle. Circ. Res. 1985, 56, 586-595. [CrossRef] [PubMed]

90. Kass, D.A.; Beyar, R.; Lankford, E.; Heard, M.; Maughan, W.L.; Sagawa, K. Influence of contractile state on curvilinearity of in situ end-systolic pressure-volume relations. Circulation 1989, 79, 167-178. [CrossRef]

91. Ruckman, R.N.; Rosenquist, G.C.; Rademaker, D.A.; Morse, D.E.; Getson, P.R. The effect of graded hypoxia on the embryonic chick heart. Teratology 1985, 32, 463-472. [CrossRef] [PubMed]

92. Keller, B.B.; Hu, N.; Clark, E.B. Correlation of ventricular area, perimeter, and conotruncal diameter with mass and function in the stage 12 to 24 chick embryo. Circ. Res. 1990, 66, 109-114. [CrossRef] [PubMed]

93. Keller, B.B.; Hu, N.; Serrino, P.J.; Clark, E.B. Ventricular pressure-area loop characteristics in the stage 16 to 24 chick embryo. Circ. Res. 1991, 68, 226-231. [CrossRef] [PubMed]

94. Keller, B.B.; Hu, N.; Tinney, J.P. Embryonic ventricular diastolic and systolic pressure-volume relation. Cardiol. Young 1994, 4, 19-27. [CrossRef]

95. Yoshigi, M.; Keller, B.B. Pressure-volume relationships of the embryonic heart analyzed by custom-developed IMAQ image analysis system [Japanese]. InterLab. 1999, 4, 58-59.

96. Tobita, K.; Keller, B.B. End-systolic myocardial stiffness is a load independent index of contractility in the stage 24 chick embryonic heart. Am. J. Physiol. 1999, 276, 2101-2108. [CrossRef]

97. Tobita, K.; Keller, B.B. Maturation of end-systolic stress-strain relations in chick embryo myocardium. Am. J. Physiol. 2000, 279, 216-224.

98. Keller, B.B.; Yoshigi, M.; Tinney, J.P. Ventricular-vascular uncoupling by acute conotruncal occlusion in the stage 21 chick embryo. Am. J. Physiol. 1997, 273, 2861-2866. [CrossRef]

99. Hu, N.; Keller, B.B. Relationship of simultaneous atrial and ventricular pressures in the stage 16 to 27 chick embryo. Am. J. Physiol. 1995, 269, 1359-1362. [CrossRef] [PubMed]

100. Campbell, K.A.; Hu, N.; Clark, E.B.; Keller, B.B. Analysis of dynamic atrial dimension and function during early cardiac development in the chick embryo. Ped. Res. 1992, 32, 333-337. [CrossRef] [PubMed]

101. Zimmerman, F.J.; Hughes, S.F.; Cuneo, B.; Benson, D.W., Jr. The effect of cardiac cycle length on ventricular end-diastolic pressure and maximum time derivative of pressure in the stage 24 chick embryo. Pediatr. Res. 1991, 29, 338-441. [CrossRef] [PubMed]

102. Cuneo, B.; Hughes, S.; Benson, D.W., Jr. Heart rate perturbation in chick embryos: A comparison of two methods. Am. J. Physiol. 1991, 260, 1864-1869. [CrossRef]

103. Cuneo, B.; Hughes, S.; Benson, D.W., Jr. Heart rate perturbation in the stage 17-27 chick embryo: Effect on stroke volume and aortic flow. Am. J. Physiol. 1993, 264, 755-759. [CrossRef] 
104. Casillas, C.B.; Tinney, J.P.; Keller, B.B. Influence of acute alterations in cycle length on ventricular function in the chick embryo. Am. J. Physiol. 1994, 267, 905-911. [CrossRef]

105. Yin, F.C.P. Ventricular/Vascular Coupling: Clinical, Physiological and Engineering Aspects; Springer-Verlag: New York, NY, USA, 1987; pp. 1-19.

106. Burkhoff, D.; Alexander, J., Jr.; Schipke, J. Assessment of Windkessel as a model of aortic input impedance. Am. J. Physiol. 1988, 255, 742-753. [CrossRef]

107. Zahka, K.G.; Hu, N.; Brin, K.P.; Yin, F.C.; Clark, E.B. Aortic impedance and hydraulic power in the chick embryo from stages 18 to 29. Circ. Res. 1989, 64, 1091-1095.

108. Yoshigi, M.; Hu, N.; Keller, B.B. Dorsal aortic impedance in the stage 24 chick embryo following acute changes in circulating blood volume. Am. J. Physiol. 1996, 270, 1597-1606. [CrossRef]

109. Yoshigi, M.; Keller, B.B. Linearity of pulsatile pressure-flow relations in the embryonic chick vascular system. Circ. Res. 1996, 79, 864-870. [CrossRef]

110. Yoshigi, M.; Keller, B.B. Characterization of the embryonic aortic impedance with lumped parameter models. Am. J. Physiol. 1997, 273, 19-27. [CrossRef] [PubMed]

111. Yoshigi, M.; Ettel, J.M.; Keller, B.B. Developmental changes in flow wave propagation velocity in the embryonic chick vascular system. Am. J. Physiol. 1997, 273, 1523-1529. [CrossRef] [PubMed]

112. Yoshigi, M.; Knott, G.; Keller, B.B. Lumped parameter estimation for the embryonic chick vascular system: A time domain approach using MLAB. Computer Programs Biomed. J. 2000, 63, 29-41. [CrossRef]

113. Shi, L.; Goenezen, S.; Haller, S.; Hinds, M.T.; Thornburg, K.L.; Rugonyi, S. Alterations in pulse wave propagation reflect the degree of outflow tract banding in HH18 chicken embryos. Am. J. Physiol. 2013, 305, 386-396. [CrossRef]

114. Bowers, P.N.; Tinney, J.P.; Keller, B.B. Nitroprusside selectively reduces ventricular preload in the stage 21 chick embryo. Cardiovasc. Res. 1996, 31, 132-138. [CrossRef]

115. Miller, C.E.; Vanni, M.A.; Taber, L.A.; Keller, B.B. Passive stress-strain measurements in the stage 16 and stage 18 embryonic chick heart. J. Biomech. Eng. 1997, 119, 445-451. [CrossRef]

116. Miller, C.E.; Vanni, M.A.; Keller, B.B. Characterization of passive embryonic myocardium by quasi-linear viscoelasticity theory. J. Biomech. 1997, 30, 985-988. [CrossRef]

117. Ling, P.; Taber, L.A.; Humphrey, J.D. Approach to quantify the mechanical behavior of the intact embryonic chick heart. Ann. Biomed. Eng. 2002, 30, 636-645. [CrossRef]

118. Barry, W.H.; Pitzen, R.; Protas, K.; Harrison, D.C. Inotropic effects of different calcium ion concentration on the embryonic chick ventricle. Comparison of single cultured cells and intact muscle strips. Circ. Res. 1975, 36, 727-734. [CrossRef]

119. Wetzel, G.T.; Chen, F.; Klitzner, T.S. Ca2+ channel kinetics in acutely isolated fetal, neonatal, and adult rabbit cardiac myocytes. Circ. Res. 1993, 72, 1065-1074. [CrossRef]

120. Tsyvian, P.B.; Routkevich, S.M.; Protsenko, Y.L.; Tsyvian, E.P.; Miller, C.E.; Keller, B.B. The role of the intraand extracellular sources in "Force-Frequency" relations in the chick embryonic myocardium. Russ. J. Physiol. 1998, 84, 1402-1411.

121. Tsyvian, P.B.; Markhasin, V.S.; Solovyeva, O.E.; Rutkevitch, S.M.; Protsenko, L.L.; Artemeva, O.G.; Schroder, E.A.; Keller, B.B. Contraction-relaxation dynamics and mechanical restitution in the developing myocardium of the chick embryo. Ross. Fiziol. Zh. Im. I. M. Sechenova. 2001, 87, 901-910.

122. Solovyeva, O.E.; Markhasin, V.S.; Tsyvian, P.B.; Keller, B.B. Experimental and theoretical investigation of force-interval relationships in the developing chick myocardium. Biofizika 1999, 44, 337-349.

123. Schroder, E.A.; Satin, J.; Routkevitch, S.; Tsyvian, P.; Keller, B.B. T-type and L-Type Calcium Currents Modulate Force in Embryonic Chick Myocardium. In Cardiac Development; Ostadal, B., Nagano, M., Dhalla, N.S., Eds.; Kluwer Academic Publishers: Boston, MA, USA, 2002; pp. 113-132.

124. Schroder, E.A.; Tobita, K.; Tinney, J.P.; Foldes, J.K.; Keller, B.B. Microtubule involvement in the adaptation to altered mechanical load in developing chick myocardium. Circ. Res. 2002, 91, 353-359. [CrossRef]

125. Omens, J.H.; Fung, Y.C. Residual strain in rat left ventricle. Circ. Res. 1990, 66, 37-45. [CrossRef]

126. Hunter, P.J.; Nielsen, P.M.; Smaill, B.H.; LeGrice, I.J.; Hunter, I.W. An anatomical heart model with applications to myocardial activation and ventricular mechanics. Crit. Rev. Biomed. Eng. 1992, 20, 403-426.

127. McCulloch, A.; Waldman, L.; Rogers, J.; Guccione, J. Large-scale finite element analysis of the beating heart. Crit. Rev. Biomed. Eng. 1992, 20, 427-449. 
128. Taber, L.A.; Keller, B.B.; Clark, E.B. Cardiac mechanics in the stage 16 chick embryo. J. Biomech. Eng. 1992, 114, 427-434. [CrossRef]

129. Taber, L.A.; Hu, N.; Pexieder, T.; Clark, E.B.; Keller, B.B. Residual strain in the embryonic ventricle of the stage 16 to 24 chick embryo heart. Circ. Res. 1993, 72, 455-462. [CrossRef]

130. Yang, M.; Taber, L.A.; Clark, E.B. A nonliner poroelastic model for the trabecular embryonic heart. J. Biomech Eng. 1994, 116, 213-223. [CrossRef]

131. Taber, L.A. Mechanical aspects of cardiac development. Prog. Biophys. Mol. Biol. 1998, 69, 237-255. [CrossRef]

132. Taber, L.A.; Sun, H.; Cartmell, J.S.; Clark, E.B.; Keller, B.B. Epicardial strains in the stage 16-24 embryonic chick ventricle. Circ. Res. 1994, 75, 896-903. [CrossRef]

133. Costa, K.D.; May-Newman, K.; Farr, D.; O’Dell, W.G.; McCulloch, A.D.; Omens, J.H. Three-dimensional residual strain in midanterior canine left ventricle. Am. J. Physiol. 1997, 273, 1968-1976. [CrossRef]

134. Tobita, K.; Keller, B.B. Ventricular epicardial deformation patterns during normal development and during the development of left heart hypoplasia in the chick embryo. Am. J. Physiol. 2000, 279, 959-969.

135. Tobita, K.; Garrison, J.B.; Liu, L.J.; Tinney, J.P.; Keller, B.B. Three dimensional myofiber architecture of the embryonic left ventricle during normal and development of altered mechanical loads. Anat. Rec. 2005, 283, 193-201. [CrossRef]

136. Damon, B.J.; Rémond, M.C.; Bigelow, M.R.; Trusk, T.C.; Xie, W.; Perucchio, R.; Sedmera, D.; Denslow, S.; Thompson, R.P. Patterns of muscular strain in the embryonic heart wall. Dev. Dyn. 2009, 238, 1535-1546. [CrossRef]

137. Smith, B.R.; Effmann, E.L.; Johnson, G.A. MR microscopy of chick embryo vasculature. J. Magn. Reson. Imaging. 1992, 2, 237-240. [CrossRef]

138. Smith, B.R. Magnetic resonance microscopy in cardiac development. Microsc.. Res. Tech. 2001, 52, 323-330. [CrossRef]

139. Yelbuz, T.M.; Choma, M.A.; Thrane, L.; Kirby, M.L.; Izatt, J.A. Optical coherence tomography: A new high-resolution imaging technology to study cardiac development in chick embryos. Circulation 2002, 106, 2771-2774. [CrossRef]

140. Manner, J.; Thrane, L.; Norozi, K.; Yelbuz, T.M. High-resolution in vivo imaging of the cross-sectional deformations of contracting embryonic heart loops using optical coherence tomography. Dev. Dyn. 2008, 237, 953-961. [CrossRef]

141. Larina, I.V.; Sudheendran, N.; Ghosn, M.; Jiang, J.; Cable, A.; Larin, K.V.; Dickinson, M.E. Live imaging of blood flow in mammalian embryos using Doppler swept-source optical coherence tomography. J. Biomed. Opt. 2008, 13. [CrossRef]

142. Wang, S.; Lakomy, D.S.; Garcia, M.D.; Lopez, A.L., 3rd; Larin, K.V.; Larina, I.V. Four-dimensional live imaging of hemodynamics in mammalian embryonic heart with Doppler optical coherence tomography. J. Biophotonics. 2016, 9, 837-847. [CrossRef]

143. Butcher, J.T.; Sedmera, D.; Guldberg, R.E.; Markwald, R.R. Quantitative volumetric analysis of cardiac morphogenesis assessed through micro-computed tomography. Dev. Dyn. 2007, 236, 802-809. [CrossRef]

144. Männer, J. Cardiac looping in the chick embryo: A morphological review with special reference to terminological and biomechanical aspects of the looping process. Anat. Rec. 2000, 259, 248-262. [CrossRef]

145. Miller, C.E.; Wong, C.L.; Sedmera, D. Pressure overload alters stress-strain properties of the developing chick heart. Am. J. Physiol. 2003, 285, 1849-1856. [CrossRef]

146. Groenendijk, B.C.; Hierck, B.P.; Vrolijk, J.; Baiker, M.; Pourquie, M.J.; Gittenberger-De Groot, A.C.; Poelmann, R.E. Changes in shear stress-related gene expression after experimentally altered venous return in the chicken embryo. Circ. Res. 2005, 96, 1291-1298. [CrossRef]

147. Vennemann, P.; Kiger, K.T.; Lindken, R.; Groenendijk, B.C.; Stekelenburg-de Vos, S.; ten Hagen, T.L.; Ursem, N.T.; Poelmann, R.E.; Westerweel, J.; Hierck, B.P. In vivo micro particle image velocimetry measurements of blood-plasma in the embryonic avian heart. J. Biomech. 2006, 39, 1191-1200. [CrossRef]

148. McQuinn, T.C.; Bratoeva, M.; Dealmeida, A.; Remond, M.; Thompson, R.P.; Sedmera, D. High-frequency ultrasonographic imaging of avian cardiovascular development. Dev. Dyn. 2007, 236, 3503-3513. [CrossRef]

149. Oosterbaan, A.M.; Ursem, N.T.; Struijk, P.C.; Bosch, J.G.; van der Steen, A.F.; Steegers, E.A. Doppler flow velocity waveforms in the embryonic chicken heart at developmental stages corresponding to 5-8 weeks of human gestation. Ultrasound Obs. Gynecol. 2009, 33, 638-644. [CrossRef] 
150. Jenkins, M.W.; Peterson, L.; Gu, S.; Gargesha, M.; Wilson, D.L.; Watanabe, M.; Rollins, A.M. Measuring hemodynamics in the developing heart tube with four-dimensional gated Doppler optical coherence tomography. J. Biomed. Opt. 2010, 15. [CrossRef]

151. Yalcin, H.C.; Shekhar, A.; McQuinn, T.C.; Butcher, J.T. Hemodynamic patterning of the avian atrioventricular valve. Dev. Dyn. 2011, 240, 23-35. [CrossRef]

152. Peterson, L.M.; Jenkins, M.W.; Gu, S.; Barwick, L.; Watanabe, M.; Rollins, A.M. 4D shear stress maps of the developing heart using Doppler optical coherence tomography. Biomed. Opt. Express. 2012, 3, 3022-3032. [CrossRef]

153. Buskohl, P.R.; Jenkins, J.T.; Butcher, J.T. Computational simulation of hemodynamic-driven growth and remodeling of embryonic atrioventricular valves. Biomech. Model. Mechanobiol. 2012, 11, 1205-1217. [CrossRef] [PubMed]

154. Buskohl, P.R.; Gould, R.A.; Butcher, J.T. Quantification of embryonic atrioventricular valve biomechanics during morphogenesis. J. Biomech. 2012, 45, 895-902. [CrossRef]

155. Karunamuni, G.H.; Gu, S.; Ford, M.R.; Peterson, L.M.; Ma, P.; Wang, Y.T.; Rollins, A.M.; Jenkins, M.W.; Watanabe, M. Capturing structure and function in an embryonic heart with biophotonic tools. Front. Physiol. 2013, 5, 351. [CrossRef] [PubMed]

156. Ma, Z.; Liu, A.; Yin, X.; Troyer, A.; Thornburg, K.; Wang, R.K.; Rugonyi, S. Measurement of absolute blood flow velocity in outflow tract of HH18 chicken embryo based on $4 \mathrm{D}$ reconstruction using spectral domain optical coherence tomography. Biomed. Opt. Express. 2010, 1, 798-811. [CrossRef]

157. Poelma, C.; Van der Heiden, K.; Hierck, B.P.; Poelmann, R.E.; Westerweel, J. Measurements of the wall shear stress distribution in the outflow tract of an embryonic chicken heart. J. R. Soc. Interface. 2010, 7, 91-103. [CrossRef]

158. Li, P.; Yin, X.; Shi, L.; Rugonyi, S.; Wang, R.K. In vivo functional imaging of blood flow and wall strain rate in outflow tract of embryonic chick heart using ultrafast spectral domain optical coherence tomography. J. Biomed. Opt. 2012, 17, 96006-96010. [CrossRef] [PubMed]

159. Liu, A.; Yin, X.; Shi, L.; Li, P.; Thornburg, K.L.; Wang, R.; Rugonyi, S. Biomechanics of the chick embryonic heart outflow tract at $\mathrm{HH} 18$ using $4 \mathrm{D}$ optical coherence tomography imaging and computational modeling. PLoS ONE 2012, 7. [CrossRef] [PubMed]

160. Ho, S.; Tan, G.X.Y.; Foo, T.J.; Phan-Thien, N.; Yap, C.H. Organ dynamics and fluid dynamics of the HH25 chick embryonic cardiac ventricle as revealed by a novel 4D high-frequency Ultrasound imaging technique and computational flow simulations. Ann. Biomed. Eng. 2017, 45, 2309-2323. [CrossRef]

161. Wang, Y.; Dur, O.; Patrick, M.J.; Tinney, J.P.; Tobita, K.; Keller, B.B.; Pekkan, K. Aortic arch morphogenesis and flow modeling in the chick embryo. Ann. Biomed. Eng. 2009, 37, 1069-1081. [CrossRef] [PubMed]

162. Kowalski, W.J.; Teslovich, N.C.; Dur, O.; Keller, B.B.; Pekkan, K. Computational hemodynamic optimization predicts dominant aortic arch selection is driven by embryonic outflow tract orientation in the chick embryo. Biomech. Model. Mechanobiol. 2012, 11, 1057-1073. [CrossRef] [PubMed]

163. Kowalski, W.J.; Dur, O.; Wang, Y.; Patrick, M.J.; Tinney, J.P.; Keller, B.B.; Pekkan, K. Critical transitions in early embryonic aortic arch patterning and hemodynamics. PLoS ONE 2013, 8. [CrossRef]

164. Kowalski, W.J.; Teslovich, N.K.; Menon, P.G.; Tinney, J.P.; Keller, B.B.; Pekkan, K. Left atrial ligation alters intracardiac flow patterns and the biomechanical landscape in the chick embryo. Dev. Dyn. S 2014, 243, 652-662. [CrossRef]

165. Goktas, S.; Uslu, F.E.; Kowalski, W.J.; Ermek, E.; Keller, B.B.; Pekkan, K. Time-series interactions of gene expression, vascular growth and hemodynamics during early embryonic arterial development. PLoS ONE 2016, 11. [CrossRef]

166. Karakaya, C.; Goktas, S.; Celik, M.; Kowalski, W.J.; Keller, B.B.; Pekkan, K. Asymmetry in mechanosensitive gene expression during aortic arch morphogenesis. Sci. Rep. 2018, 8, 16948. [CrossRef]

167. Benslimane, F.M.; Alser, M.; Zakaria, Z.Z.; Sharma, A.; Abdelrahman, H.A.; Yalcin, H.C. Adaptation of a mice Doppler echocardiography platform to measure cardiac flow velocities for embryonic chicken and adult zebrafish. Front. Bioeng. Biotechnol. 2019, 7, 96. [CrossRef]

168. Tobita, K.; Schroder, E.A.; Tinney, J.P.; Garrison, J.B.; Keller, B.B. Regional passive ventricular pressure-strain relations during development of altered loads in the chick embryo. Am. J. Physiol. 2002, 282, 2386-2396.

169. Buffinton, C.M.; Faas, D.; Sedmera, D. Stress and strain adaptation in load-dependent remodeling of the embryonic left ventricle. Biomech. Model. Mechanobiol. 2013, 12, 1037-1051. [CrossRef] 
170. Chivukula, V.K.; Goenezen, S.; Liu, A.; Rugonyi, S. Effect of outflow tract banding on embryonic cardiac hemodynamics. J. Cardiovasc. Dev. Dis. 2016, 3, 1. [CrossRef] [PubMed]

171. Lindsey, S.E.; Menon, P.G.; Kowalski, W.J.; Shekhar, A.; Yalcin, H.C.; Nishimura, N.; Schaffer, C.B.; Butcher, J.T.; Pekkan, K. Growth and hemodynamics after early embryonic aortic arch occlusion. Biomech. Model. Mechanobiol. 2015, 14, 735-751. [CrossRef] [PubMed]

172. Midgett, M.; Chivukula, V.K.; Dorn, C.; Wallace, S.; Rugonyi, S. Blood flow through the embryonic heart outflow tract during cardiac looping in HH13-HH18 chicken embryos. J. R. Soc. Interface 2015, 12. [CrossRef]

173. Midgett, M.; López, C.S.; David, L.; Maloyan, A.; Rugonyi, S. Increased hemodynamic load in early embryonic stages alters myofibril and mitochondrial organization in the myocardium. Front. Physiol. 2017, 8, 631. [CrossRef] [PubMed]

174. Rennie, M.Y.; Stovall, S.; Carson, J.P.; Danilchik, M.; Thornburg, K.L.; Rugonyi, S. Hemodynamics modify collagen deposition in the early embryonic chicken heart outflow tract. J. Cardiovasc. Dev. Dis. 2017, 4, 24. [CrossRef]

175. Celik, M.; Goktas, S.; Karakaya, C.; Cakiroglu, A.I.; Karahuseyinoglu, S.; Lashkarinia, S.S.; Ermek, E.; Pekkan, K. Microstructure of early embryonic aortic arch and its reversibility following mechanically-altered hemodynamic load release. Am. J. Physiol. 2020. [CrossRef]

176. Pang, K.L.; Parnall, M.; Loughna, S. Effect of altered haemodynamics on the developing mitral valve in chick embryonic heart. J. Mol. Cell. Cardiol. 2017, 108, 114-126. [CrossRef]

177. Menon, V.; Eberth, J.F.; Goodwin, R.L.; Potts, J.D. Altered hemodynamics in the embryonic heart affects outflow valve development. J. Cardiovasc. Dev. Dis. 2015, 2, 108-124. [CrossRef]

178. Biechler, S.V.; Junor, L.; Evans, A.N.; Eberth, J.F.; Price, R.L.; Potts, J.D.; Yost, M.J.; Goodwin, R.L. The impact of flow-induced forces on the morphogenesis of the outflow tract. Front. Physiol. 2014, 5, 225. [CrossRef]

179. Perdios, C.; Parnall, M.; Pang, K.L.; Loughna, S. Altered haemodynamics causes aberrations in the epicardium. J. Anat. 2019, 234, 800-814. [CrossRef]

180. Harh, J.Y.; Paul, M.H.; Gallen, W.J.; Friedberg, D.Z.; Kaplan, S. Experimental production of hypoplastic left heart syndrome in the chick embryo. Am. J. Cardiol. 1973, 31, 51-56. [CrossRef]

181. Sedmera, D.; Pexieder, T.; Rychterova, V.; Hu, N.; Clark, E.B. Remodeling of chick embryonic ventricular myoarchitecture under experimentally changed loading conditions. Anat. Rec. 1999, 254, 238-252. [CrossRef]

182. Sedmera, D.; Hu, N.; Weiss, K.M.; Keller, B.B.; Denslow, S.; Thompson, R.P. Cellular changes in experimental left heart hypoplasia. Anat. Rec. 2002, 267, 137-145. [CrossRef] [PubMed]

183. Hu, N.; Christensen, D.A.; Agrawal, A.K.; Beaumont, C.; Clark, E.B.; Hawkins, J.A. Dependence of aortic arch morphogenesis on intracardiac blood flow in the left atrial ligated chick embryo. Anat. Rec. (Hoboken) 2009, 292, 652-660. [CrossRef]

184. McCaffrey, F.M.; Sherman, F.S. Prenatal diagnosis of severe aortic stenosis. Pediatr. Cardiol. 1997, 18, $276-281$. [CrossRef]

185. Mäkikallio, K.; McElhinney, D.B.; Levine, J.C.; Marx, G.R.; Colan, S.D.; Marshall, A.C.; Lock, J.E.; Marcus, E.N.; Tworetzky, W. Fetal aortic valve stenosis and the evolution of hypoplastic left heart syndrome: Patient selection for fetal intervention. Circulation. 2006, 113, 1401-1405. [CrossRef]

186. Sedmera, D.; Harris, B.S.; Grant, E.; Zhang, N.; Jourdan, J.; Kurkova, D.; Gourdie, R.G. Cardiac expression patterns of endothelin-converting enzyme (ECE): Implications for conduction system development. Dev. Dyn. 2008, 237, 1746-5317. [CrossRef]

187. Pesevski, Z.; Kvasilova, A.; Stopkova, T.; Nanka, O.; Drobna Krejci, E.; Buffinton, C.; Kockova, R.; Eckhardt, A.; Sedmera, D. Endocardial fibroelastosis is secondary to hemodynamic alterations in the chick embryonic model of hypoplastic left heart syndrome. Dev. Dyn. 2018, 247, 509-520. [CrossRef]

188. Van der Heiden, K.; Groenendijk, B.C.; Hierck, B.P.; Hogers, B.; Koerten, H.K.; Mommaas, A.M.; Gittenberger-de Groot, A.C.; Poelmann, R.E. Monocilia on chicken embryonic endocardium in low shear stress areas. Dev. Dyn. 2006, 235, 19-28. [CrossRef]

189. Ricci, M.; Xu, Y.; Hammond, H.L.; Willoughby, D.A.; Nathanson, L.; Rodriguez, M.M.; Vatta, M.; Lipshultz, S.E.; Lincoln, J. Myocardial alternative RNA splicing and gene expression profiling in early stage hypoplastic left heart syndrome. PLOS ONE 2012, 7. [CrossRef]

190. Sucharov, C.C.; Sucharov, J.; Karimpour-Fard, A.; Nunley, K.; Stauffer, B.L.; Miyamoto, S.D. Micro-RNA expression in hypoplastic left heart syndrome. J. Card. Fail. 2015, 21, 83-88. [CrossRef] 
191. Gambetta, K.; Al-Ahdab, M.K.; Ilbawi, M.N.; Hassaniya, N.; Gupta, M. Transcription repression and blocks in cell cycle progression in hypoplastic left heart syndrome. Am. J. Physiol. 2008, 294, 2268-2275. [CrossRef]

192. Thompson, R.; Lindroth, J.R.; Wong, Y.M.M. Regional differences in DNA-synthetic activity in the preseptation myocardium of the chick. In Developmental Cardiology: Morphogenesis and Function; Clark, E.B., Takao, A., Eds.; Futura Publishing Co: Mount Kisco, NY, USA, 1990; pp. 219-234.

193. Thompson, R.P.; Kanai, T.; Germroth, P.G.; Gourdie, R.G.; Chan-Thomas, P.; Barton, P.J.R.; Mikawa, T.; Anderson, R.H. Organization and function of early specialized myocardium. In Developmental Mechanisms of Heart Disease; Clark, E.B., Markwald, R.R., Takao, A., Eds.; Futura Publishing Co: Mount Kisco, NY, USA, 1995; pp. 269-280.

194. Gourdie, R.G.; Mima, T.; Thompson, R.P.; Mikawa. T. Terminal diversification of the myocyte lineage generates Purkinje fibers of the cardiac conduction system. Development 1995, 121, 1423-1431.

195. Reckova, M.; Rosengarten, C.; deAlmeida, A.; Stanley, C.P.; Wessels, A.; Gourdie, R.G.; Thompson, R.P.; Sedmera, D. Hemodynamics is a key epigenetic factor in development of the cardiac conduction system. Circ. Res. 2003, 93, 77-85. [CrossRef]

196. Hall, C.E.; Hurtado, R.; Hewett, K.W.; Shulimovich, M.; Poma, C.P.; Reckova, M.; Justus, C.; Pennisi, D.J.; Tobita, K.; Sedmera, D.; et al. Hemodynamic-dependent patterning of endothelin converting enzyme 1 expression and differentiation of impulse-conducting Purkinje fibers in the embryonic heart. Development 2004, 131, 581-592. [CrossRef]

197. Hogers, B.; Deruiter, M.C.; Baasten, A.M.; Gittenberger-De Groot, A.C.; Poelmann, R.E. Intracardiac blood flow patterns related to the yolk sac circulation of the chick embryo. Circ. Res. 1995, 76, 871-877. [CrossRef]

198. Hogers, B.; Deruiter, M.C.; Gittenberger-De Groot, A.C.; Poelmann, R.E. Extraembryonic venous obstructions lead to cardiovascular malformations and can be embryo lethal. Cardiovasc. Res. 1999, 41, 87-99. [CrossRef]

199. Hogers, B.; van der Weerd, L.; Olofsen, H.; van der Graaf, L.M.; DeRuiter, M.C.; Gittenberger-de Groot, A.C.; Poelmann, R.E. Non-invasive tracking of avian development in vivo by MRI. NMR Biomed. 2009, 22, 365-373. [CrossRef] [PubMed]

200. Broekhuizen, M.L.; Bouman, H.G.; Mast, F.; Mulder, P.G.; Gittenberger-De Groot, A.C.; Wladimiroff, J.W. Hemodynamic changes in $\mathrm{HH}$ stage 34 chick embryos after treatment with all-trans-retinoic acid. Pediatr. Res. 1995, 38, 342-348. [CrossRef] [PubMed]

201. Broekhuizen, M.L.; Hogers, B.; DeRuiter, M.C.; Poelmann, R.E.; Gittenberger-de Groot, A.C.; Wladimiroff, J.W. Altered hemodynamics in chick embryos after extraembryonic venous obstruction. Ultrasound. Obstet. Gynecol. 1999, 13, 437-445. [CrossRef] [PubMed]

202. Stekelenburg-De Vos, S.; Ursem, N.T.; Hop, W.C.; Wladimiroff, J.W.; Gittenberger-De Groot, A.C.; Poelmann, R.E. Acutely altered hemodynamics following venous obstruction in the early chick embryo. J. Exp. Biol. 2003, 206, 1051-1057. [CrossRef] [PubMed]

203. Stekelenburg-De Vos, S.; Steendijk, P.; Ursem, N.T.; Wladimiroff, J.W.; Delfos, R.; Poelmann, R.E. Systolic and dias2olic ventricular function assessed by pressure-volume loops in the stage 21 venous clipped chick embryo. Pediatr. Res. 2005, 57, 16-21. [CrossRef] [PubMed]

204. Stekelenburg-de Vos, S.; Steendijk, P.; Ursem, N.T.; Wladimiroff, J.W.; Poelmann, R.E. Systolic and diastolic ventricular function in the normal and extra-embryonic venous clipped chicken embryo of stage 24: A pressure-volume loop assessment. Ultrasound. Obstet. Gynecol. 2007, 30, 325-331. [CrossRef] [PubMed]

205. Ursem, N.T.; Stekelenburg-de Vos, S.; Wladimiroff, J.W.; Poelmann, R.E.; Gittenberger-de Groot, A.C.; Hu, N.; Clark, E.B. Ventricular diastolic filling characteristics in stage-24 chick embryos after extra-embryonic venous obstruction. J. Exp. Biol. 2004, 207, 1487-1490. [CrossRef] [PubMed]

206. Groenendijk, B.C.; Hierck, B.P.; Gittenberger-de Groot, A.C.; Poelmann, R.E. Development-related changes in the expression of shear stress responsive genes KLF-2, ET-1, and NOS-3 in the developing cardiovascular system of chicken embryos. Dev. Dyn. 2004, 230, 57-68. [CrossRef] [PubMed]

207. Groenendijk, B.C.; Van der Heiden, K.; Hierck, B.P.; Poelmann, R.E. The role of shear stress on ET-1, KLF2, and NOS-3 expression in the developing cardiovascular system of chicken embryos in a venous ligation model. Physiology (Bethesda). 2007, 22, 380-389. [CrossRef]

208. Groenendijk, B.C.; Stekelenburg-de Vos, S.; Vennemann, P.; Wladimiroff, J.W.; Nieuwstadt, F.T.; Lindken, R.; Westerweel, J.; Hierck, B.P.; Ursem, N.T.; Poelmann, R.E. The endothelin-1 pathway and the development of cardiovascular defects in the hemodynamically challenged chicken embryo. J. Vasc. Res. 2008, 45, 54-68. [CrossRef] 
209. Kurihara, Y.; Kurihara, H.; Oda, H.; Maemura, K.; Nagai, R.; Ishikawa, T.; Yazaki, Y. Aortic arch malformations and ventricular septal defect in mice deficient in endothelin-1. J. Clin. Investig. 1995, 96, 293-300. [CrossRef]

210. Lee, T.C.; Zhao, Y.D.; Courtman, D.W.; Stewart, D.J. Abnormal aortic valve development in mice lacking endothelial nitric oxide synthase. Circulation 2000, 101, 2345-2348. [CrossRef]

211. Gessner, I.H. Spectrum of congenital cardiac anomalies produced in chick embryos by mechanical interference with cardiogenesis. Circ. Res. 1966, 18, 625-633. [CrossRef]

212. Clark, E.B.; Rosenquist, G.C. Spectrum of cardiovascular anomalies following cardiac loop constriction in the chick embryo. Birth Defects Orig. Artic. Ser. 1978, 14, 431-442. [PubMed]

213. Clark, E.B.; Hu, N.; Rosenquist, G.C. Effect of conotruncal constriction on aortic-mitral valve continuity in the stage 18, 21 and 24 chick embryo. Am. J. Cardiol. 1984, 53, 324-327. [CrossRef]

214. Clark, E.B.; Hu, N.; Frommelt, P.; Vandekieft, G.K.; Dummett, J.L.; Tomanek, R.J. Effect of increased pressure on ventricular growth in stage 21 chick embryos. Am. J. Physiol. 1989, 257, 55-61. [CrossRef] [PubMed]

215. Engelmann, G.L.; Campbell, S.E.; Rakusan, K. Immediate postnatal rat heart development modified by abdominal aortic banding: analysis of gene expression. Mol. Cell Biochem. 1996, 163-164, 47-56. [CrossRef] [PubMed]

216. Anversa, P.; Ricci, R.; Olivetti, G. Quantitative structural analysis of the myocardium during physiologic growth and induced cardiac hypertrophy: A review. J. Am. Coll. Cardiol. 1986, 7, 1140-1149. [CrossRef]

217. Sedmera, D.; Thompson, R.P. Myocyte proliferation in the developing heart. Dev. Dyn. 2011, 240, $1322-1334$. [CrossRef]

218. Parnall, M.; Perdios, C.; Pang, K.L.; Rochette, S.; Loughna, S. Characterization of the developing heart in a pressure overloaded model utilizing RNA sequencing to direct functional analysis. J. Anat. 2020, 236, 549-563. [CrossRef]

219. Menon, V.; Eberth, J.F.; Junor, L.; Potts, A.J.; Belhaj, M.; Dipette, D.J.; Jenkins, M.W.; Potts, J.D. Removing vessel constriction on the embryonic heart results in changes in valve gene expression, morphology, and hemodynamics. Dev. Dyn. 2018, 247, 531-541. [CrossRef]

220. Lucitti, J.L.; Tobita, K.; Keller, B.B. Arterial hemodynamics and mechanical properties after circulatory intervention in the chick embryo. J. Exp. Biol. 2005, 208, 1877-1885. [CrossRef]

221. Lucitti, J.L.; Visconti, R.; Novak, J.; Keller, B.B. Increased arterial load alters aortic structural and functional properties during embryogenesis. Am. J. Physiol. 2006, 291, 1919-1926. [CrossRef]

222. Kirby, M.; Stewart, D. Adrenergic innervation of the developing chick heart: Neural crest ablations to produce sympathetically aneural hearts. Am. J. Anat. 1984, 171, 295-305. [CrossRef]

223. Kirby, M.L.; Stewart, D.E. Neural crest origin of cardiac ganglion cells in the chick embryo: Identification and extirpation. Dev. Biol. 1983, 97, 433-443. [CrossRef]

224. Kirby, M.L.; Turnage, K.L., 3rd; Hays, B.M. Characterization of conotruncal malformations following ablation of "cardiac" neural crest. Anat. Rec. 1985, 213, 87-93. [CrossRef] [PubMed]

225. Hutson, M.R.; Kirby, M.L. Neural crest and cardiovascular development: A 20-year perspective. Birth Defects Res. C. Embryo Today. 2003, 69, 2-13. [CrossRef] [PubMed]

226. Stewart, D.E.; Kirby, M.L.; Sulik, K.K. Hemodynamic changes in chick embryos precede heart defects after cardiac neural crest ablation. Circ. Res. 1986, 59, 545-550. [CrossRef] [PubMed]

227. Tomita, H.; Connuck, D.M.; Leatherbury, L.; Kirby, M.L. Relation of early hemodynamic changes to final cardiac phenotype and survival after neural crest ablation in chick embryos. Circulation 1991, 84, 1289-1295. [CrossRef] [PubMed]

228. Leatherbury, L.; Connuck, D.M.; Gauldin, H.E.; Kirby, M.L. Hemodynamic changes and compensatory mechanisms during early cardiogenesis after neural crest ablation in chick embryos. Pediatr. Res. 1991, 30, 509-512. [CrossRef] [PubMed]

229. Conway, S.J.; Godt, R.E.; Hatcher, C.J.; Leatherbury, L.; Zolotouchnikov, V.V.; Brotto, M.A.; Copp, A.J.; Kirby, M.L.; Creazzo, T.L. Neural crest is involved in development of abnormal myocardial function. J. Mol. Cell. Cardiol. 1997, 29, 2675-2685. [CrossRef]

230. Nosek, T.M.; Fogaça, R.T.; Hatcher, C.J.; Brotto, M.A.; Godt, R.E. Effect of cardiac neural crest ablation on contractile force and calcium uptake and release in chick heart. Am. J. Physiol. 1997, 273, 1464-1471. [CrossRef]

231. Creazzo, T.L.; Wang, Q.; Godt, R.E. Colocalization of dihydropyridine and ryanodine receptors in developing heart with a neural crest-associated defect. Exp. Clin. Cardiol. 2001, 6, 11-16. 
232. Keller, B.B.; MacLennan, M.J.; Tinney, J.P.; Yoshigi, M. In vivo assessment of embryonic cardiovascular dimensions and function in day 10.5 To 14.5 mouse embryos. Circ. Res. 1996, 79, 247-255. [CrossRef]

233. Furukawa, S.; MacLennan, M.J.; Keller, B.B. Hemodynamic response to anesthesia in pregnant and nonpregnant ICR mice. Lab. Animal Sci. 1998, 48, 357-363.

234. Furukawa, S.; Tinney, J.P.; Tobita, K.; Keller, B.B. Hemodynamic vulnerability to acute hypoxia in day 10.5-16.5 murine embryos. J. Obstet. Gynecol. Res. 2007, 33, 114-127. [CrossRef] [PubMed]

235. Aristizábal, O.; Christopher, D.A.; Foster, F.S.; Turnbull, D.H. 40-MHZ echocardiography scanner for cardiovascular assessment of mouse embryos. Ultrasound. Med. Biol. 1998, 24, 1407-1417. [CrossRef]

236. Foster, F.S.; Zhang, M.Y.; Zhou, Y.Q.; Liu, G.; Mehi, J.; Cherin, E.; Harasiewicz, K.A.; Starkoski, B.G.; Zan, L.; Knapik, D.A.; et al. A new ultrasound instrument for in vivo microimaging of mice. Ultrasound. Med. Biol. 2002, 28, 1165-1172. [CrossRef]

237. Huang, C.; Sheikh, F.; Hollander, M.; Cai, C.; Becker, D.; Chu, P.H.; Evans, S.; and Chen, J. Embryonic atrial function is essential for mouse embryogenesis, cardiac morphogenesis and angiogenesis. Development 2003, 130, 6111-6119. [CrossRef] [PubMed]

238. Ishiwata, T.; Nakazawa, M.; Pu, W.T.; Tevosian, S.G.; Izumo, S. Developmental changes in ventricular diastolic function correlate with changes in ventricular myoarchitecture in normal mouse embryos. Circ. Res. 2003, 93, 857-865. [CrossRef]

239. Zhou, Y.Q.; Foster, F.S.; Parkes, R.; Adamson, S.L. Developmental changes in left and right ventricular diastolic filling patterns in mice. Am. J. Physiol. 2003, 285, 1563-1575. [CrossRef]

240. Jones, E.A.; Baron, M.H.; Fraser, S.E.; Dickinson, M.E. Measuring hemodynamic changes during mammalian development. Am. J. Physiol. 2004, 287, 1561-1569. [CrossRef] [PubMed]

241. Slevin, J.C.; Byers, L.; Gertsenstein, M.; Qu, D.; Mu, J.; Sunn, N.; Kingdom, J.C.; Rossant, J.; Adamson, S.L. High resolution ultrasound-guided microinjection for interventional studies of early embryonic and placental development in vivo in mice. BMC Dev. Biol. 2006, 6, 10. [CrossRef]

242. Hoog, T.G.; Fredrickson, S.J.; Hsu, C.W.; Senger, S.M.; Dickinson, M.E.; Udan, R.S. The effects of reduced hemodynamic loading on morphogenesis of the mouse embryonic heart. Dev. Biol. 2018, 442, 127-137. [CrossRef] [PubMed]

243. Gui, Y.H.; Linask, K.K.; Khowsathit, P.; Huhta, J.C. Doppler echocardiography of normal and abnormal embryonic mouse heart. Pediatr. Res. 1996, 40, 633-642. [CrossRef] [PubMed]

244. Momoi, N.; Tinney, J.P.; Keller, B.B.; Tobita, K. Maternal hypoxia and caffeine exposure depress fetal cardiovascular function during primary organogenesis. J. Obstet. Gynecol. Res. 2012, 38, 1343-1351. [CrossRef] [PubMed]

245. Momoi, N.; Tinney, J.P.; Liu, L.J.; Elshershari, H.; Hoffmann, P.J.; Ralphe, J.C.; Keller, B.B.; Tobita, K. Modest maternal caffeine exposure affects developing embryonic cardiovascular function and growth. Am. J. Physiol. 2008, 294, 2248-2256. [CrossRef]

246. Ursem, N.T.C.; Brinkman, H.J.F.; Struijk, P.C.; Hop, W.C.J.; Kempski, M.H.; Keller, B.B.; Wladimiroff, J.W. Umbilical artery waveform analysis based on maximum, mean, and mode velocity in early human pregnancy. Ultrasound Med. Biol. 1998, 24, 1-7. [CrossRef]

247. Ursem, N.T.C.; Clark, E.B.; Keller, B.B.; Hop, W.C.J.; Wladimiroff, J.W. Assessment of fetal heart rate and velocity variability by Doppler velocimetry of the descending aorta at 10-20 weeks of gestation. Ultrasound Obstet. Gynecol. 1999, 14, 397-401. [CrossRef]

248. Phoon, C.K.; Aristizabal, O.; Turnbull, D.H. 40 MHz Doppler characterization of umbilical and dorsal aortic blood flow in the early mouse embryo. Ultrasound Med. Biol. 2000, 26, 1275-1283. [CrossRef]

249. Phoon, C.K.; Aristizábal, O.; Turnbull, D.H. Spatial velocity profile in mouse embryonic aorta and Doppler-derived volumetric flow: A preliminary model. Am. J. Physiol. 2002, 283, 908-916. [CrossRef] [PubMed]

250. Phoon, C.K.; Ji, R.P.; Aristizábal, O.; Worrad, D.M.; Zhou, B.; Baldwin, H.S.; Turnbull, D.H. Embryonic heart failure in NFATc1-/- mice: Novel mechanistic insights from in utero ultrasound biomicroscopy. Circ. Res. 2004, 95, 92-99. [CrossRef] [PubMed]

251. Struijk, P.C.; Ursem, N.T.C.; Mathews, J.; Clark, E.B.; Keller, B.B.; Wladimiroff, J.W. Power spectrum analysis of heart rate and blood flow velocity variability in the umbilical artery and uterine artery in early pregnancy. A comparative study. Ultrasound Obstet. Gynecol. 2001, 17, 316-321. [CrossRef] [PubMed] 
252. Zhou, Y.Q.; Foster, F.S.; Qu, D.W.; Zhang, M.; Harasiewicz, K.A.; Adamson, S.L. Applications for multifrequency ultrasound biomicroscopy in mice from implantation to adulthood. Physiol. Genom. 2002, 10, 113-126. [CrossRef]

253. MacLennan, M.J.; Keller, B.B. Murine embryonic umbilical arterial velocity during development and following acutely increased heart rate. Ultrasound Med. Biol. 1999, 25, 361-370. [CrossRef]

254. Yashiro, K.; Shiratori, H.; Hamada, H. Hemodynamics determined by a genetic programme govern asymmetric development of the aortic arch. Nature 2007, 450, 285-288. [CrossRef]

255. Shen, Y.; Leatherbury, L.; Rosenthal, J.; Yu, Q.; Pappas, M.A.; Wessels, A.; Lucas, J.; Siegfried, B.; Chatterjee, B.; Svenson, K.; et al. Cardiovascular phenotyping of fetal mice by noninvasive high-frequency ultrasound facilitates recovery of ENU-induced mutations causing congenital cardiac and extracardiac defects. Physiol. Genom. 2005, 24, 24,23-36. [CrossRef]

256. Liu, X.; Tobita, K.; Francis, R.J.; Lo, C.W. Imaging techniques for visualizing and phenotyping congenital heart defects in murine models. Birth Defects Res. C. Embryo Today. 2013, 99, 93-105. [CrossRef]

257. Liu, X.; Francis, R.; Kim, A.J.; Ramirez, R.; Chen, G.; Subramanian, R.; Anderton, S.; Kim, Y.; Wong, L.; Morgan, J.; et al. Interrogating congenital heart defects with noninvasive fetal echocardiography in a mouse forward genetic screen. Circ. Cardiovasc. Imaging. 2014, 7, 31-42. [CrossRef]

258. Liu, X.; Kim, A.J.; Reynolds, W.; Wu, Y.; Lo, C.W. Phenotyping cardiac and structural birth defects in fetal and newborn mice. Birth Defects Res. 2017, 109, 778-790. [CrossRef]

259. Cleary, J.O.; Price, A.N.; Thomas, D.L.; Scambler, P.J.; Kyriakopoulou, V.; McCue, K.; Schneider, J.E.; Ordidge, R.J.; Lythgoe, M.F. Cardiac phenotyping in ex vivo murine embryos using microMRI. NMR Biomed. 2009, 22, 857-866. [CrossRef]

260. Stainier, D.Y.; Fishman, M.C. The zebrafish as a model system to study cardiovascular development. Trends Cardiovasc. Med. 1994, 4, 207-212. [CrossRef]

261. Hu, N.; Sedmera, D.; Yost, H.J.; Clark, E.B. Structure and function of the developing zebrafish heart. Anat. Rec. 2000, 260, 148-157. [CrossRef]

262. Hove, J.R.; Köster, R.W.; Forouhar, A.S.; Acevedo-Bolton, G.; Fraser, S.E.; Gharib, M. Intracardiac fluid forces are an essential epigenetic factor for embryonic cardiogenesis. Nature 2003, 421, 172-177. [CrossRef]

263. Bartman, T.; Walsh, E.C.; Wen, K.K.; McKane, M.; Ren, J.; Alexander, J.; Rubenstein, P.A.; Stainier, D.Y. Early myocardial function affects endocardial cushion development in zebrafish. PLoS Biol. 2004, 2, 129. [CrossRef]

264. Forouhar, A.S.; Liebling, M.; Hickerson, A.; Nasiraei-Moghaddam, A.; Tsai, H.J.; Hove, J.R.; Fraser, S.E.; Dickinson, M.E.; Gharib, M. The embryonic vertebrate heart tube is a dynamic suction pump. Science 2006, 312, 751-753. [CrossRef]

265. Liebling, M.; Forouhar, A.S.; Wolleschensky, R.; Zimmermann, B.; Ankerhold, R.; Fraser, S.E.; Gharib, M.; Dickinson, M.E. Rapid three-dimensional imaging and analysis of the beating embryonic heart reveals functional changes during development. Dev. Dyn. 2006, 235, 2940-2948. [CrossRef]

266. Denvir, M.A.; Tucker, C.S.; Mullins, J.J. Systolic and diastolic ventricular function in zebrafish embryos: Influence of norepenephrine, MS-222 and temperature. BMC Biotechnol. 2008, 8, 21. [CrossRef]

267. Shin, J.T.; Pomerantsev, E.V.; Mably, J.D.; MacRae, C.A. High-resolution cardiovascular function confirms functional orthology of myocardial contractility pathways in zebrafish. Physiol. Genom. 2010, 42, 300-309. [CrossRef]

268. Chen, C.Y.; Patrick, M.J.; Corti, P.; Kowalski, W.J.; Roman, B.L.; Pekkan, K. Analysis of early embryonic great-vessel microcirculation in zebrafish using high-speed confocal $\mu$ PIV. Biorheology 2011, 48, 305-321. [CrossRef]

269. Anton, H.; Harlepp, S.; Ramspacher, C.; Wu, D.; Monduc, F.; Bhat, S.; Liebling, M.; Paoletti, C.; Charvin, G.; Freund, J.B.; et al. Pulse propagation by a capacitive mechanism drives embryonic blood flow. Development 2013, 140, 4426-4434. [CrossRef]

270. Jamison, R.A.; Samarage, C.R.; Bryson-Richardson, R.J.; Fouras, A. In vivo wall shear measurements within the developing zebrafish heart. PLoS ONE 2013, 8. [CrossRef]

271. Kalogirou, S.; Malissovas, N.; Moro, E.; Argenton, F.; Stainier, D.Y.; Beis, D. Intracardiac flow dynamics regulate atrioventricular valve morphogenesis. Cardiovasc. Res. 2014, 104, 49-60. [CrossRef]

272. Boselli, F.; Vermot, J. Live imaging and modeling for shear stress quantification in the embryonic zebrafish heart. Methods 2016, 9, 129-134. [CrossRef] 
273. Boselli, F.; Steed, E.; Freund, J.B.; Vermot, J. Anisotropic shear stress patterns predict the orientation of convergent tissue movements in the embryonic heart. Development 2017, 144, 4322-4327. [CrossRef]

274. Bark, D.L., Jr.; Johnson, B.; Garrity, D.; Dasi, L.P. Valveless pumping mechanics of the embryonic heart during cardiac looping: Pressure and flow through micro-PIV. J. Biomech. 2017, 50, 50-55. [CrossRef]

275. Yalcin, H.C.; Amindari, A.; Butcher, J.T.; Althani, A.; Yacoub, M. Heart function and hemodynamic analysis for zebrafish embryos. Dev. Dyn. 2017, 246, 868-880. [CrossRef]

276. Battista, N.A.; Douglas, D.R.; Lane, A.N.; Samsa, L.A.; Liu, J.; Miller, L.A. Vortex Dynamics in Trabeculated Embryonic Ventricles. J. Cardiovasc. Dev. Dis. 2019, 6, 6. [CrossRef]

277. Sidhwani, P.; Yelon, D. Fluid forces shape the embryonic heart: Insights from zebrafish. Curr. Top. Dev. Biol. 2019, 132, 395-416.

278. Salman, H.E.; Yalcin, H.C. Advanced blood flow assessment in Zebrafish via experimental digital particle image velocimetry and computational fluid dynamics modelling. Micron 2020, 130. [CrossRef]

279. Dietrich, A.C.; Lombardo, V.A.; Veerkamp, J.; Priller, F.; Abdelilah-Seyfried, S. Blood flow and Bmp signaling control endocardial chamber morphogenesis. Dev. Cell 2014, 30, 367-377. [CrossRef]

280. Goddard, L.M.; Duchemin, A.L.; Ramalingan, H.; Wu, B.; Chen, M.; Bamezai, S.; Yang, J.; Li, L.; Morley, M.P.; Wang, T.; et al. Hemodynamic forces sculpt developing heart valves through a KLF2-WNT9B paracrine signaling axis. Dev. Cell 2017, 43, 274-289.

281. Taylor, J.M.; Nelson, C.J.; Bruton, F.A.; Baghbadrani, A.K.; Buckley, C.; Tucker, C.S.; Rossi, A.G.; Mullins, J.J.; Denvir, M.A. Adaptive prospective optical gating enables day-long 3D time-lapse imaging of the beating embryonic zebrafish heart. Nat. Commun. 2019, 10, 5073. [CrossRef]

282. Sato, M.; Yost, H.J. Cardiac neural crest contributes to cardiomyogenesis in zebrafish. Dev. Biol. 2003, 257, 127-139. [CrossRef]

283. Banjo, T.; Grajcarek, J.; Yoshino, D.; Osada, H.; Miyasaka, K.Y.; Kida, Y.S.; Ueki, Y.; Nagayama, K.; Kawakami, K.; Matsumoto, T.; et al. Haemodynamically dependent valvulogenesis of zebrafish heart is mediated by flow-dependent expression of miR-21. Nat. Commun. 2013, 4, 1978. [CrossRef]

284. Cordes, K.R.; Srivastava, D. MicroRNA regulation of cardiovascular development. Circ. Res. 2009, 104, 724-732. [CrossRef]

285. Ursem, N.T.C.; Clark, E.B.; Keller, B.B.; Wladimiroff, J.W. Fetal heart rate and umbilical artery velocity variability in pregnancies complicated by insulin-dependent diabetes mellitus. Ultrasound Obstet. Gynecol. 1999, 13, 312-316. [CrossRef]

286. Ursem, N.T.C.; Clark, E.B.; Keller, B.B.; Hop, W.C.J.; Wladimiroff, J.W. Do heart rate and velocity variability derived from umbilical artery velocity waveforms change prior to clinical pregnancy induced hypertension? Ultrasound Obstet. Gynecol. 1999, 14, 244-249. [CrossRef]

287. Acharya, G.; Gui, Y.; Cnota, W.; Huhta, J.; Wloch, A. Human embryonic cardiovascular function. Acta. Obstet. Gynecol. Scand. 2016, 95, 621-628. [CrossRef]

288. Chang, C.P.; Bruneau, B.G. Epigenetics and cardiovascular development. Annu. Rev. Physiol. 2012, 74, 41-68. [CrossRef]

289. Srivastava, D. Genetic regulation of cardiogenesis and congenital heart disease. Annu. Rev. Pathol. 2006, 1, 199-249. [CrossRef]

290. Pierpont, M.E.; Basson, C.T.; Benson, D.W.J.; Gelb, B.D.; Giglia, T.M.; Goldmuntz, E.; McGee, G.; Sable, C.A.; Srivastava, D.; Webb, C.L. American Heart Association Congenital Cardiac Defects Committee; Council on Cardiovascular Disease in the Young. Genetic basis for congenital heart defects: Current knowledge: A scientific statement from the American Heart Association Congenital Cardiac Defects Committee, Council on Cardiovascular Disease in the Young: Endorsed by the American Academy of Pediatrics. Circulation 2007, 115, 3015-3038.

291. Pierpont, M.E.; Brueckner, M.; Chung, W.K.; Garg, V.; Lacro, R.V.; McGuire, A.L.; Mital, S.; Priest, J.R.; $\mathrm{Pu}$, W.T.; Roberts, A.; et al. Genetic basis for congenital heart disease: Revisited: A scientific statement from the american heart association. Circulation 2018, 138, 653-7011. [CrossRef]

292. Fahed, A.C.; Gelb, B.D.; Seidman, J.G.; Seidman, C.E. Genetics of congenital heart disease: The glass half empty. Circ. Res. 2013, 112, 707-720. [CrossRef] [PubMed]

293. Gelb, B.D.; Chung, W.K. Complex genetics and the etiology of human congenital heart disease. Cold Spring Harb. Perspect. Med. 2014, 4. [CrossRef] 
294. Edwards, J.J.; Gelb, B.D. Genetics of congenital heart disease. Curr. Opin. Cardiol. 2016, 31, $235-241$. [CrossRef]

295. Zaidi, S.; Brueckner, M. Genetics and genomics of congenital heart disease. Circ. Res. 2017, 120, 923-940. [CrossRef]

296. Drews, J.D.; Pepper, V.K.; Best, C.A.; Szafron, J.M.; Cheatham, J.P.; Yates, A.R.; Hor, K.N.; Zbinden, J.C.; Chang, Y.C.; Mirhaidari, G.J.M.; et al. Spontaneous reversal of stenosis in tissue-engineered vascular grafts. Sci. Transl. Med. 2020, 12. [CrossRef] [PubMed]

297. Miyagawa, S.; Domae, K.; Yoshikawa, Y.; Fukushima, S.; Nakamura, T.; Saito, A.; Sakata, Y.; Hamada, S.; Toda, K.; Pak, K.; et al. Phase I clinical trial of autologous stem cell-sheet transplantation therapy for treating cardiomyopathy. J. Am. Heart. Assoc. 2017, 6. [CrossRef] [PubMed]

298. Bittle, G.J.; Morales, D.; Deatrick, K.B.; Parchment, N.; Saha, P.; Mishra, R.; Sharma, S.; Pietris, N.; Vasilenko, A.; Bor, C.; et al. Stem cell therapy for hypoplastic left heart syndrome: Mechanism, clinical application, and future directions. Circ Res. 2018, 123, 288-300. [CrossRef]

(C) 2020 by the authors. Licensee MDPI, Basel, Switzerland. This article is an open access article distributed under the terms and conditions of the Creative Commons Attribution (CC BY) license (http://creativecommons.org/licenses/by/4.0/). 